\title{
Spatial, temporal and source contribution assessments of black carbon over the northern interior of South Africa
}

\author{
Kgaugelo Euphinia Chiloane ${ }^{1}$, Johan Paul Beukes ${ }^{1}$, Pieter Gideon van Zyl ${ }^{1}$, Petra Maritz ${ }^{1}$, Ville Vakkari ${ }^{2}$, \\ Miroslav Josipovic ${ }^{1}$, Andrew Derick Venter ${ }^{1}$, Kerneels Jaars ${ }^{1}$, Petri Tiitta ${ }^{1,3}$, Markku Kulmala ${ }^{4}$, \\ Alfred Wiedensohler ${ }^{5}$, Catherine Liousse ${ }^{6}$, Gabisile Vuyisile Mkhatshwa ${ }^{7}$, Avishkar Ramandh ${ }^{8}$, and Lauri Laakso ${ }^{1,2}$ \\ ${ }^{1}$ Unit for Environmental Sciences and Management, North-West University, Potchefstroom Campus, South Africa \\ ${ }^{2}$ Finnish Meteorological Institute, Helsinki, Finland \\ ${ }^{3}$ Department of Environmental and Biological Sciences, University of Eastern Finland, P.O. Box 1627, Kuopio, Finland \\ ${ }^{4}$ Department of Physics, University of Helsinki, Helsinki, Finland \\ ${ }^{5}$ Leibniz Institute for Tropospheric Research, Leipzig, Germany \\ ${ }^{6}$ Laboratoire d'Aérologie, Université Paul Sabatier-CNRS, OMP, 14 Avenue Edouard Belin, Toulouse, France \\ ${ }^{7}$ Research, Testing and Development, Eskom SOC Ltd, Rosherville, South Africa \\ ${ }^{8}$ Sasol Technology R\&D (Pty) Limited, Sasolburg, South Africa
}

Correspondence to: Johan Paul Beukes (paul.beukes@nwu.ac.za)

Received: 19 October 2016 - Discussion started: 29 November 2016

Revised: 17 April 2017 - Accepted: 18 April 2017 - Published: 19 May 2017

\begin{abstract}
After carbon dioxide $\left(\mathrm{CO}_{2}\right)$, aerosol black carbon (BC) is considered to be the second most important contributor to global warming. This paper presents equivalent black carbon (eBC) (derived from an optical absorption method) data collected from three sites in the interior of South Africa where continuous measurements were conducted, i.e. Elandsfontein, Welgegund and Marikana, as well elemental carbon (EC) (determined by evolved carbon method) data at five sites where samples were collected once a month on a filter and analysed offline, i.e. Louis Trichardt, Skukuza, Vaal Triangle, Amersfoort and Botsalano.

Analyses of eBC and EC spatial mass concentration patterns across the eight sites indicate that the mass concentrations in the South African interior are in general higher than what has been reported for the developed world and that different sources are likely to influence different sites. The mean eBC or EC mass concentrations for the background sites (Welgegund, Louis Trichardt, Skukuza, Botsalano) and sites influenced by industrial activities and/or nearby settlements (Elandsfontein, Marikana, Vaal Triangle and Amersfoort) ranged between 0.7 and 1.1 , and 1.3 and $1.4 \mu \mathrm{g} \mathrm{m}^{-3}$, respectively.
\end{abstract}

Similar seasonal patterns were observed at all three sites where continuous measurement data were collected (Elandsfontein, Marikana and Welgegund), with the highest eBC mass concentrations measured from June to October, indicating contributions from household combustion in the cold winter months (June-August), as well as savannah and grassland fires during the dry season (May to mid-October). Diurnal patterns of eBC at Elandsfontein, Marikana and Welgegund indicated maximum concentrations in the early mornings and late evenings, and minima during daytime. From the patterns it could be deduced that for Marikana and Welgegund, household combustion, as well as savannah and grassland fires, were the most significant sources, respectively.

Possible contributing sources were explored in greater detail for Elandsfontein, with five main sources being identified as coal-fired power stations, pyrometallurgical smelters, traffic, household combustion, as well as savannah and grassland fires. Industries on the Mpumalanga Highveld are often blamed for all forms of pollution, due to the $\mathrm{NO}_{2}$ hotspot over this area that is attributed to $\mathrm{NO}_{x}$ emissions from industries and vehicle emissions from the Johannesburg-Pretoria megacity. However, a comparison of source strengths indicated that household combustion as well as savannah and grassland fires were the most significant sources of eBC, par- 
ticularly during winter and spring months, while coal-fired power stations, pyrometallurgical smelters and traffic contribute to eBC mass concentration levels year round.

\section{Introduction}

Aerosol black carbon (BC) is the carbonaceous fraction of ambient particulate matter that absorbs incoming short-wave solar radiation and terrestrial long-wave radiation, which has a warming effect on the atmosphere (IPCC, 2013). Although $\mathrm{BC}$ has a relatively short atmospheric lifetime (days to weeks), it has significant regional effects on temperature, cloud amount and precipitation. Over snow-covered areas, the surface albedo can be significantly reduced due to the deposition of $\mathrm{BC}$, and this may considerably influence the local and regional climate (Ramanathan and Carmichael, 2008; Jacobson, 2004). Direct observations of reduced albedo resulting from long-range-transported BC into Arctic areas were reported by Stohl (2006). It was estimated that BC may have contributed to more than half of the observed Arctic warming since 1890 , most of this occurring during the last three decades (Shindell et al., 2008). After $\mathrm{CO}_{2}$, $\mathrm{BC}$ is considered to be the second most important contributor to global warming (Bond et al., 2004; IPCC, 2013). According to some authors, reducing $\mathrm{BC}$ emissions may be the fastest means of slowing global warming in the near future. In addition to the aforementioned effects, $\mathrm{BC}$ is a major contributor to fine particulate matter in the atmosphere that can also have negative health effects (Hansen et al., 1984, Cachier, 1995; IPCC, 2013).

Atmospheric BC is a primary species (Putaud et al., 2004; Pöschl, 2005) that is emitted by combustion processes, particularly from fossil fuel combustion, diesel engine exhaust, as well as open biomass fires and household combustion (Cachier, 1995; Cooke and Wilson, 1996; Bond et al., 2004; IPCC, 2013). Globally, approximately $20 \%$ of BC is emitted from residential biofuel burning, $40 \%$ from fossil fuels and $40 \%$ from open biomass burning such as forest and savannah fires (Cooke and Wilson, 1996; Wolf and Cachier, 1998; Pope et al., 2002). BC from fossil fuels is estimated to contribute a global mean radiative forcing of 0.04 watts per square metre $\left(\mathrm{W} \mathrm{m}^{-2}\right)$ (IPCC, 2013).

There are large uncertainties associated with emissions of $\mathrm{BC}$, its aging during atmospheric transportation and its removal by precipitation (Bond and Sun, 2004), which are reflected in uncertainties in the global effect of BC (e.g. Bond et al., 2013). Presently, the majority of aerosol radiative impact assessments are based on models (Bond et al., 2013; IPCC, 2013), both on local and global scales, which incorporate measured aerosol properties. However, this approach involves several assumptions (e.g. assuming aerosol properties and the use of global instead of regional emission inventories for under-sampled/characterised regions). Considering the relatively short atmospheric lifetime of $\mathrm{BC}$, such assumptions could lead to significant uncertainties, especially on regional scales (Andreae and Gelencsér, 2006; Masiello, 2004; Bond et al., 2013; Kuik et al., 2015). For a better understanding of the transport, removal and climatic impacts of atmospheric BC, accurate and up-to-date measurements covering large spatial areas and long temporal periods are required.

Africa is one of the least studied continents, although it is regarded as the largest source region of atmospheric BC (Liousse et al., 1996; Kanakidou et al., 2005). Southern Africa is an important sub-source region, with savannah and grassland fires (anthropogenic and natural) being prevalent across this region, particularly during the dry season, when almost no precipitation occurs (Formenti et al., 2003; Tummon et al., 2010; Laakso et al., 2012; Vakkari et al., 2014; Mafusire et al., 2016). Studies by Swap et al. (2004) indicated that savannah and grassland fire plumes from southern Africa affect Australia and South America. South Africa is the economic and industrial hub of southern Africa with large anthropogenic point sources (Lourens et al., 2011). However, the relative importance of $\mathrm{BC}$ contributions from these anthropogenic sources in South Africa is still largely unknown and few BC-related papers have been published in the peer-reviewed public domain. Venter et al. (2012) used BC mass concentration data collected at the Marikana monitoring station to verify the origin of $\mathrm{CO}$ and $\mathrm{PM}_{10}$ but did not consider BC further. Collett et al. (2010) only presented a single diurnal plot for $\mathrm{BC}$ mass concentration measured at the Elandsfontein monitoring station in 2010. Hyvärinen et al. (2013) used BC mass concentration data collected at the Welgegund monitoring station to illustrate the use of a newly developed method to correct $\mathrm{BC}$ mass concentration values measured with a multi-angle absorption photometer (MAAP). In addition, Martins (2009) determined elemental carbon (EC) and organic carbon (OC) mass concentrations from three 2-week winter campaigns and one 2week summer campaign at two sites, as part of the framework of the Deposition of Biogeochemical Important Trace Species (DEBITS)-International Global Atmospheric Chemistry (IGAC) in Africa project (Galy-Lacaux et al., 2003; Martins et al., 2007). However, these data have not yet been published in the peer-reviewed scientific domain. Maritz et al. (2015) and Aurela et al. (2016) presented limited EC mass concentration data from some regional background sites in South Africa. Kuik et al. (2015) used the Weather Research and Forecasting model, including chemistry and aerosols (WRF-Chem), to analyse the contribution of anthropogenic emissions to the total tropospheric BC mass concentrations from September to December 2010 in South Africa. However, significant underestimations and uncertainties with regard to $\mathrm{BC}$ mass concentrations were reported by the aforementioned authors.

From the above-mentioned information, the need for improved BC mass concentration data for South Africa is evident. This paper presents spatial and temporal assessments 


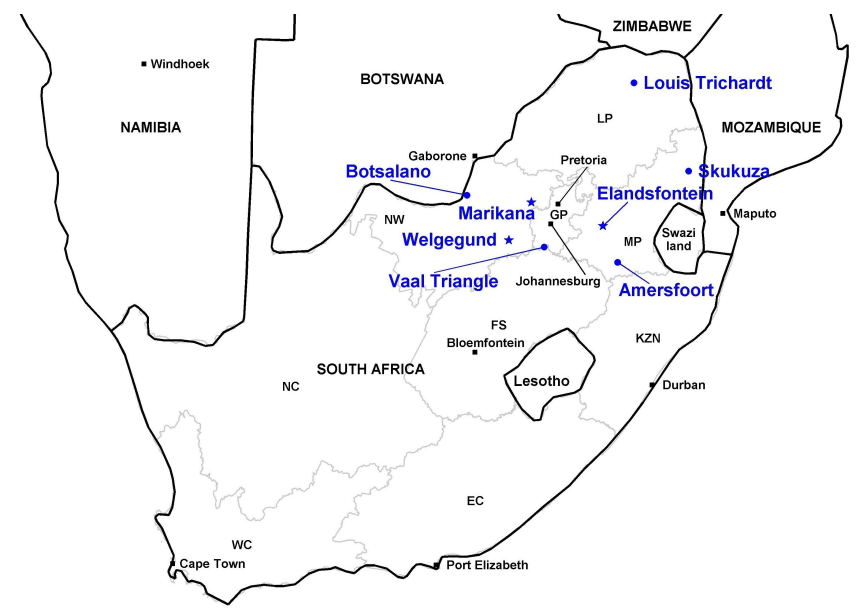

Figure 1. The sites (Elandsfontein, Welgegund and Marikana) where continuous high-resolution data were gathered are indicated with blue stars, while the sites (Louis Trichardt, Skukuza, Vaal Triangle, Amersfoort and Botsalano) where filters were gathered and analysed offline are indicated with blue dots. Neighbouring countries, some major cities and South African provincial borders are also indicated for additional regional contextualisation (Provinces include WC - Western Cape; EC - Eastern Cape; NC - Northern Cape; FS - Free State; KZN - KwaZulu-Natal; NW - North West; GP - Gauteng; MP - Mpumalanga and LP - Limpopo).

of equivalent black carbon (eBC) derived from an optical absorption method and EC determined by an evolved carbon method (definitions according to Petzold et al., 2013) for mass concentrations over the northern interior of South Africa, as well as potential contributing sources of eBC at Elandsfontein, a site located on the South African Highveld.

\section{Measurement locations and methods}

\subsection{Measurement sites}

In this paper, $\mathrm{eBC}$ or $\mathrm{EC}$ mass concentration data from eight measurement stations are presented. At three of these stations, continuous high-resolution $\mathrm{eBC}$ measurements were conducted, i.e. Elandsfontein, Welgegund and Marikana, while at the remaining five stations, i.e. Louis Trichardt, Skukuza, Vaal Triangle, Amersfoort and Botsalano, samples were collected once a month on a filter for a period of $24 \mathrm{~h}$ and analysed offline to yield EC. The locations of these sites within a regional context are indicated in Fig. 1. In order to contextualise all the sites, a brief description of each site is presented below.

\subsubsection{Elandsfontein}

The Elandsfontein monitoring station $\left(26.25^{\circ} \mathrm{S}, 29.42^{\circ} \mathrm{E}\right.$; 1750 m.a.m.s.l.) is located on the top of a hill approximately $200 \mathrm{~km}$ east of Johannesburg in the highly industrialised South African Highveld (Collett et al., 2010). The site is relatively frequently affected by plumes from coal-fired power stations, metallurgical smelters and a large petrochemical operation all of which occur within an approximately $60 \mathrm{~km}$ radius around the site (Laakso et al., 2012). The site was used for the European Integrated Project on Cloud Climate, Aerosols and Air Quality Interactions (EUCAARI) project for measurements outside Europe, with state-of-the-art instruments for comprehensive aerosol measurements (Laakso et al., 2012; Kulmala et al., 2009). Measurements were conducted from February 2009 to January 2011 with a PM $_{10}$ inlet.

\subsubsection{Marikana}

The Marikana monitoring station $\left(25.70^{\circ} \mathrm{S}, 27.48^{\circ} \mathrm{E}\right.$; 1170 m.a.m.s.l.) is located in a small village situated approximately $35 \mathrm{~km}$ east of the city of Rustenburg, in the North West province of South Africa. Within an approximately $55 \mathrm{~km}$ radius from this site, there are 11 pyrometallurgical smelters and at least twice as many mines (feeding the aforementioned smelters) (Venter et al., 2012). However, there were no mining and/or industrial activities within a $1 \mathrm{~km}$ radius of the site. The closest surroundings included semiformal (government-built housing developments, mostly with some form of informal housing additions by the occupants) and informal (self-erected, sometimes unauthorised, mostly without municipal services) settlements, a formal residential area with a gas station and shops, as well as tarred and untarred roads serving the communities in this area (Venter et al., 2012; Hirsikko et al., 2012). Measurements were conducted from September 2008 to May 2010 with a PM $_{10}$ inlet.

\subsubsection{Welgegund}

The Welgegund measurement station (www.welgegund.org; $26.57^{\circ} \mathrm{S}, 26.94^{\circ} \mathrm{E} ; 1480$ m.a.m.s.l.) is situated approximately $100 \mathrm{~km}$ west of Johannesburg on the property of a commercial farmer. It is representative of a regional background site but is also affected by aged plumes from major source regions in South Africa (Jaars et al., 2014; Tiitta et al., 2014; Venter et al., 2016). A detailed description of the Welgegund measurement station and related source regions was relatively recently presented by Beukes et al. (2013a, b). Measurements reported in this paper covered the period June 2010 to May 2012. A PM $_{10}$ inlet was used from 1 June 2010 to 25 August 2010, as well as 1 September 2011 to 31 May 2012, while a $\mathrm{PM}_{1}$ inlet was used from $26 \mathrm{Au}$ gust 2010 to 31 August 2011. The $\mathrm{PM}_{1}$ inlet sampling period was undertaken to better quantify $\mathrm{PM}_{1}$ aerosol chemical 
composition, which was reported in a previous paper (Tiitta et al., 2014).

\subsubsection{DEBITS sites}

Maritz et al. (2015) introduced all the DEBITS sites for which data are presented. Therefore, only synopses of the site descriptions, taken from the aforementioned paper, are given here. The DEBITS project is an international long-term project that mainly focuses on measuring atmospheric deposition of pollutants (Galy-Lacaux et al., 2003; Mphepya et al., 2004, 2006; Conradie et al., 2016). The Louis Trichardt $\left(22.99^{\circ} \mathrm{S}, 30.02^{\circ} \mathrm{E} ; 1300\right.$ m.a.m.s.1.), Skukuza $\left(24.99^{\circ} \mathrm{S}, 31.58^{\circ} \mathrm{E}\right.$; 267 m.a.m.s.l.), Vaal Triangle (26.72 ${ }^{\circ} \mathrm{S}, 27.88^{\circ} \mathrm{E} ; 1320$ m.a.m.s.1.), Amersfoort $\left(27.07^{\circ} \mathrm{S}\right.$, $29.87 \mathrm{E} ; 1628$ m.a.m.s.1.) and Botsalano $\left(25.54^{\circ} \mathrm{S}, 25.75^{\circ} \mathrm{E}\right.$; 1424 m.a.m.s.l.) sites were operated within the aforementioned programme. Amersfoort is situated in a grassland biome and is affected by anthropogenic activities on the Mpumalanga Highveld. Louis Trichardt is a rural site that is predominantly used for agricultural purposes within the savannah biome. Skukuza is a regional background site within the savannah biome and is situated in a protected area (Kruger National Park). The Vaal Triangle site is within the grassland biome and is situated in a highly industrialised area, affected by emissions from various industries, traffic and household combustion. Botsalano is a regional background site that is situated within the savannah biome and a protected area (Botsalano Game Reserve). In this paper, EC sampled at these sites with a $\mathrm{PM}_{10}$ inlet was reported for the period March 2009 to April 2011.

\subsection{Sampling and analysis methods}

Aerosol BC mass concentration can be measured using both online and offline methods. In this paper, eBC was measured with a light-absorption method and EC with a thermo-optical method (Petzold et al., 2013).

\subsubsection{Online sampling and analysis of $\mathrm{eBC}$}

eBC mass concentration was continuously measured at Elandsfontein, Marikana and Welgegund with a Thermo Scientific model 5012 multi-angle absorption photometer (MAAP) with time resolutions of $1 \mathrm{~min}$ that were converted to $15 \mathrm{~min}$ averages. The MAAP measures aerosol eBC with a filter-based method that uses a combination of reflection and transmission measurements together with a radiative transfer model to yield eBC concentration (Petzold and Schönlinner, 2004). However, if the automated filter change in MAAP occurs at a high eBC concentration, an artefact may occur (Hyvärinen et al., 2013). In this study, the MAAP eBC measurements were corrected for this artefact according to Hyvärinen et al. (2013). Furthermore, the MAAPs at Welgegund and Elandsfontein were operated at reduced flow rates, which decreased the number of such filter change artefacts.

\subsubsection{Offline sampling and analysis of EC}

There were $24 \mathrm{~h} \mathrm{PM}_{10}$ aerosol samples collected on quartz filters (with a deposit area of $12.56 \mathrm{~cm}^{2}$ ) once a month at Louis Trichardt, Skukuza, Vaal Triangle, Amersfoort and Botsalano for the entire measurement period reported. Sample preparation and analysis were done according to the methods described by Maritz et al. (2015). The quartz filters were prebaked at $900^{\circ} \mathrm{C}$ for $4 \mathrm{~h}$ and cooled down in a desiccator prior to sample collection. MiniVol samplers developed by the United States Environmental Protection Agency (USEPA) and the Lane Regional Air Pollution Authority were used during sampling (Baldauf et al., 2001). In this study, samples were collected at a flow rate of $5 \mathrm{~L} \mathrm{~min}^{-1}$, which was verified by using a hand-held flow meter. Filters were handled with tweezers while wearing surgical gloves as a precautionary measure to prevent possible contamination of the filters. All thermally pretreated filters were also visually inspected to ensure that there were no weak spots or flaws. After inspection, acceptable filters were weighed and packed in airtight Petri dish holders until they were used for sampling. After sampling, the filters were again placed in Petri dish holders, sealed off, bagged and stored in a portable refrigerator for transport to the laboratory. At the laboratory, the sealed filters were stored in a conventional refrigerator. At $24 \mathrm{~h}$ prior to analysis, samples were removed from the refrigerator and weighed prior to analysis. Several methods can be used to analyse EC collected on filters (Chow et al., 2001). In this study, the IMPROVE thermal/optical (TOR) protocol (Chow et al., 1993, 2004; Environmental Analysis Facility, 2008; Guillaume et al., 2008) was applied using a Desert Research Institute (DRI) analyser. With this method, the filters are subjected to volatilisation at temperatures of 120, 250, 450 and $550{ }^{\circ} \mathrm{C}$ in a pure helium $(\mathrm{He})$ atmosphere and at temperatures of 550,700 and $800^{\circ} \mathrm{C}$ in a mixture of $\mathrm{He}(98 \%)$ and oxygen $\left(\mathrm{O}_{2}\right)(2 \%)$ atmosphere. In this process, carbon compounds that are released are converted to $\mathrm{CO}_{2}$ in an oxidation furnace with a manganese dioxide $\left(\mathrm{MnO}_{2}\right)$ catalyst at $932{ }^{\circ} \mathrm{C}$. Then, the flow passes through a digester where the $\mathrm{CO}_{2}$ is reduced to methane $\left(\mathrm{CH}_{4}\right)$ on a nickel-catalysed reaction surface. The amount of $\mathrm{CH}_{4}$ formed is detected by a flame ionisation detector (FID), which is converted to carbon mass using a calibration coefficient. The carbon mass peaks detected correspond to the different temperatures at which the seven separate carbon fractions, which include three EC fractions, were released. These fractions were depicted as different peaks on the thermogram, of which the surface areas were proportional to the amount of $\mathrm{CH}_{4}$ detected. The DRI instrument can detect EC as low as $0.1 \mu \mathrm{g} \mathrm{cm}^{-2}$. 


\subsection{Savannah and grassland fire locations}

A number of products can be used to obtain savannah and grassland fire locations. Fire locations presented in this paper were obtained from the remote sensing observations of fires from the MODIS collection 5 burned area product (Roy et al., 2008).

\subsection{Air mass back-trajectory analysis}

The Hybrid Single-Particle Lagrangian Integrated Trajectory (HYSPLIT, 2014) model (version 4.8), developed by the National Oceanic and Atmospheric Administration (NOAA) Air Resources Laboratory (ARL), was used to calculate air mass histories (Draxler and Hess, 2004). Meteorological data from the GDAS archive of the National Centre for Environmental Prediction (NCEP) of the United States National Weather Service (USNWS) and archived by the ARL (Air Resources Laboratory, 2014a) were used as input. These data have a 40 or $80 \mathrm{~km}$ grid resolution, depending on the year considered (NASA, 2015), with all the data used in this study having $40 \mathrm{~km}$ grid resolution. All trajectories were calculated for $24 \mathrm{~h}$ backwards to arrive on the hour at an arrival height of $100 \mathrm{~m}$ above ground level. An arrival height of $100 \mathrm{~m}$ was chosen since the orography in HYSPLIT is not well defined, which could result in increased error margins on individual trajectory calculations if lower arrival heights are used (Air Resources Laboratory, 2014b). For such calculated back trajectories, maximum error margins of 15 to $30 \%$ of the trajectory distance travelled have been estimated (Stohl, 1998; Riddle et al., 2006).

\subsection{Linking ground-based measurements with point sources using back trajectories}

This method was introduced by Maritz et al. (2015) who used it to link ambient OC and EC concentrations to potential sources. The same method was applied here to assess if large point sources and informal or semiformal settlements contributed to ambient eBC concentrations at the sites where active eBC data were gathered (Elandsfontein, Welgegund and Marikana). The method was not applied to sites where $24 \mathrm{~h}$ composite EC samples were taken (Louis Trichardt, Skukuza, Vaal Triangle, Amersfoort and Botsalano). The method relates eBC concentrations measured at a particular sampling site with the closest distance between the hourly arriving trajectory and the aforementioned sources (large point sources, as well as informal and semiformal settlements). Figure 2 presents an illustration of the method applied for a specific sampling site to determine the shortest distance between a $24 \mathrm{~h}$ back trajectory and large point sources. The distances between the large point sources (indicated by the black markers) and a specific back trajectory were calculated for each of the hourly locations of the $24 \mathrm{~h}$ back trajectory (indicated by the red dots in Fig. 2). The red line indicates

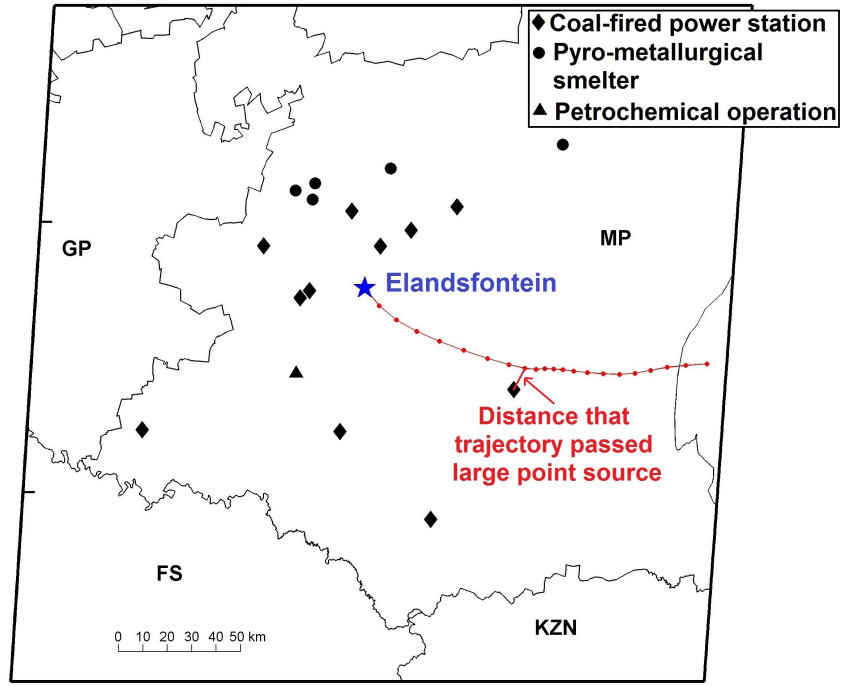

Figure 2. Example to illustrate the method applied to determine the shortest distance that each $24 \mathrm{~h}$ back trajectory passed large point sources and/or informal or semiformal settlements. (Provinces include FS - Free State, KZN - KwaZulu-Natal, NW - North West, GP - Gauteng and MP - Mpumalanga).

the shortest distance between hourly locations of this specific trajectory and large point sources (i.e. petrochemical operations, coal-fired power stations and pyrometallurgical smelters). A weakness of the aforementioned method was that downwind point sources and/or informal or semiformal settlements, very close to the monitoring site, could in some instances be the closest point source/informal or semiformal settlements. Additionally, dilution due to distance travelled by the trajectories was not considered.

\subsection{Determining the relative contribution of $\mathrm{eBC}$ from sources}

In order to determine the relative strength of eBC mass concentration sources, detailed correlation analyses were performed for eBC peaks. For instance, it is well known that plumes from coal-fired power stations on the Mpumalanga Highveld are characterised by a simultaneous increase in $\mathrm{NO}, \mathrm{NO}_{2}$ and $\mathrm{SO}_{2}$ concentrations (Collect et al., 2010; Lourens et al., 2011). Figure 3 shows the eBC, $\mathrm{SO}_{2}, \mathrm{NO}_{2}$, $\mathrm{NO}$ and $\mathrm{H}_{2} \mathrm{~S}$ data measured on 14 February 2009. In this figure, it is evident that two well-defined coal-fired power plant plumes were observed between 09:15 and 11:30 LT based on $\mathrm{SO}_{2}, \mathrm{NO}_{2}$ and $\mathrm{NO}$ time series, as well as between 18:00 and 21:00 LT. However, both of these coal-fired power plantassociated plumes did not raise the baseline eBC meaningfully. There was, however, a significant eBC plume between 02:00 and 08:30 LT, which coincided perfectly with a simultaneous increase in $\mathrm{H}_{2} \mathrm{~S}$. This eBC plume was therefore associated with the source that emitted the $\mathrm{H}_{2} \mathrm{~S}$. For each such plume, the excess eBC $(\triangle \mathrm{eBC})$ was determined, with the 
baseline defined as the linear line between the starting and end $\mathrm{eBC}$ concentrations of the observed plume and $\triangle \mathrm{eBC}$ defined as the eBC concentration above the baseline, as indicated in the top panel of Fig. 3.

\subsection{Multiple linear regression analysis}

Several techniques were applied in this paper to characterise possible sources of eBC mass concentrations measured at the various stations, e.g. seasonal patterns, diurnal patterns, back-trajectory analyses and identifying sources based on coincidental increases in species time series. In an attempt to further critically evaluate deductions made from these methods, multiple linear regression (MLR) analyses were conducted. Linear regression is denoted by constants or known parameters $(c)$, an independent variable $(x)$ and a dependent variable $(y)$ by fitting a linear equation to the observed data. MLR is characterised by more than one independent variable $(x)$. In MLR, the relationship between the dependent variable $(y)$ and independent variables $(x)$ is denoted by Eq. (1).

$y=c_{0}+c_{1} x_{1}+c_{2} x_{2}+c_{3} x_{3}+\ldots \ldots \ldots \ldots \ldots \ldots c_{z} x_{z}$

In this study, MLR was used to determine an equation for the dependent variable eBC. MLR was used to determine the optimum combination of independent variables to derive an equation that could be used to calculate eBC concentrations. Root mean square error (RMSE) was used to compare the calculated values with the measured values. Several authors have previously applied similar methods for various atmospheric species (e.g. Awang et al., 2015; Du Preez et al., 2015; Venter et al., 2015).

\section{Results and discussions}

\subsection{Spatial variation}

In Fig. 4, a box-and-whisker plot indicating the statistical eBC or EC mass concentrations for each of the sites is presented. The significant difference in number of samples $(N)$ is due to the fact that, at the DEBITS sites, EC mass concentrations were only measured once per month over a 24sampling period, whereas at the other sites, $1 \mathrm{~min}$ eBC data were collected that were converted to $15 \mathrm{~min}$ averages. Precaution should also be taken when directly comparing eBC and $\mathrm{EC}$, since it was previously proven that eBC and EC concentrations can differ by up to a factor of 7 among different methods, with a factor of 2 differences being common (Watson et al., 2005). However, an unpublished 12-month interncomparison of eBC and EC at the Welgegund measurement site, with the actual sampling and analysis equipment used to acquire data for this study, proved that EC and eBC were within the same order of magnitude (Sehloho, 2017). Therefore, notwithstanding the limitations in directly comparing EC and eBC data, Fig. 4 gives the most realistic spatial perspective for the northern interior of South Africa, especially within the context of very little other data being available in the peer-reviewed public domain.

Of all the sites considered, the highest mass concentrations were measured at Vaal Triangle that had a median EC of $3.2 \mu \mathrm{g} \mathrm{m}^{-3}$ and a mean of $4.4 \mu \mathrm{g} \mathrm{m}^{-3}$ for the entire measurement period. Although sources will be considered in greater detail later, the higher EC mass concentration levels at Vaal Triangle can be attributed to various possible sources. Firstly, this area is densely populated with large semiformal and informal settlements. This indicates that household combustion for space heating and cooking could be a significant source of EC. Secondly, the area experiences relatively higher traffic volumes and several large point sources (including petrochemical and related chemical industries, two coal-fired power stations and numerous metallurgical smelters) occur in the area. Thirdly, the site experiences less dilution due to the close proximity of the sources to the measurement site that contribute to the observed elevated levels of EC mass concentration.

The eBC at Elandsfontein, as well as the EC at Marikana and Amersfoort sites indicated similar levels with median and mean values of 0.8 and 1.3, 1.2 and 1.7, and 1.1 and $1.4 \mu \mathrm{g} \mathrm{m}^{-3}$, respectively. Elandsfontein and Amersfoort lie within the well-known $\mathrm{NO}_{2}$ hotspot over the Mpumalanga Highveld identified from satellite observations (Lourens et al., 2012) and are therefore likely to be influenced by industrial activities in this area. Marikana can be affected by household combustion from informal and semiformal settlements that are located close to the measurement site, as well as the large pyrometallurgical sources occurring in the area (Venter et al., 2012; Hirsikko et al., 2012).

The background sites, i.e. Welgegund, Botsalano, Louis Trichardt and Skukuza, had lower eBC or EC levels compared to other locations, with median and mean concentrations of 0.4 and $0.7,0.7$ and $0.9,0.8$ and 0.9 , and 0.9 and $1.1 \mathrm{~g} \mathrm{~m} \mathrm{~m}^{-3}$, respectively. All these background sites are likely to be affected most by regional savannah and grassland fires that are common in southern Africa or by pollutants transported from other parts of the country. However, Welgegund, which is the furthest west of these sites, is likely to be affected less by savannah and grassland fires due to the dryer biomes, i.e. the Kalahari and Karoo, that are located to the west of this site. These drier biome regions produce less biomass that can burn (Mafusire et al., 2016). It is therefore understandable that Welgegund had lower eBC levels than the other background sites. Obviously, Elandsfontein, Marikana, Vaal Triangle and Amersfoort will also be affected by regional savannah and grassland fires, in addition to the possible sources already mentioned.

The eBC and EC concentrations presented for all the sites considered (Fig. 4) should also be contextualised. The background site with the lowest $\mathrm{PM}_{10}$ eBC concentrations reported here, i.e. Welgegund, had similar or higher eBC mass concentration values than typical western European background sites. BC mass concentrations of less than 0.2 to 

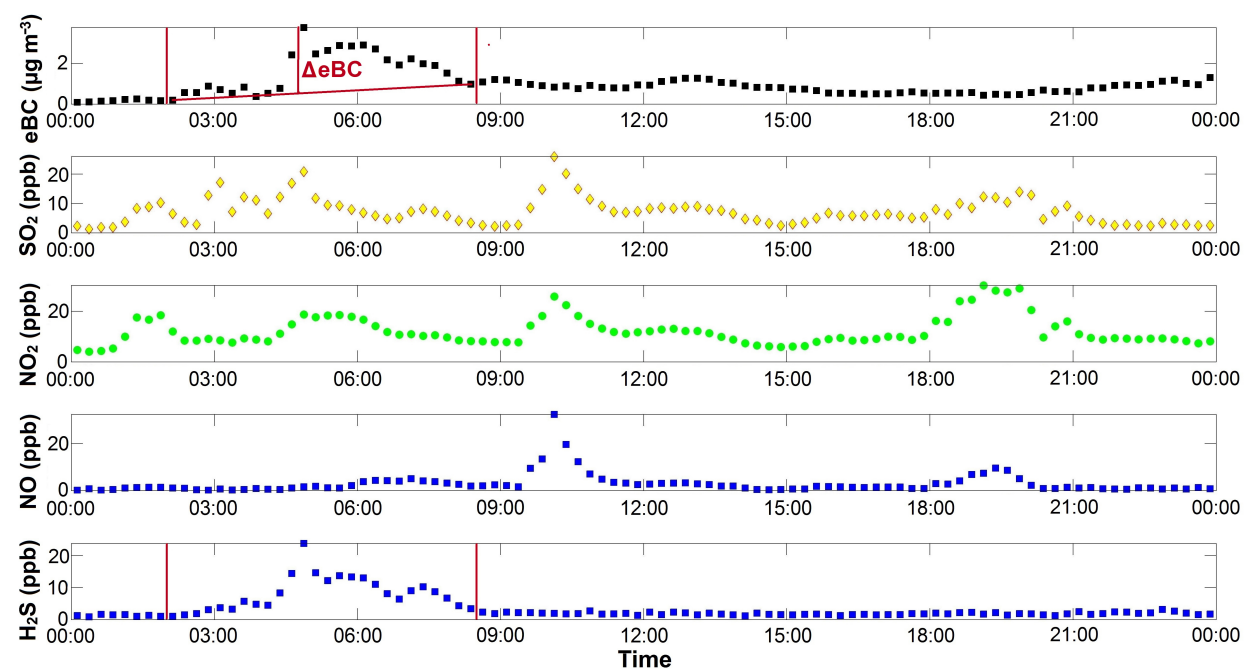

Figure 3. Example to illustrate how species were correlated with eBC in order to separate sources from one another. The excess eBC ( $\triangle \mathrm{eBC})$, defined as the eBC concentration above the baseline for this example, is also indicated in the top panel.

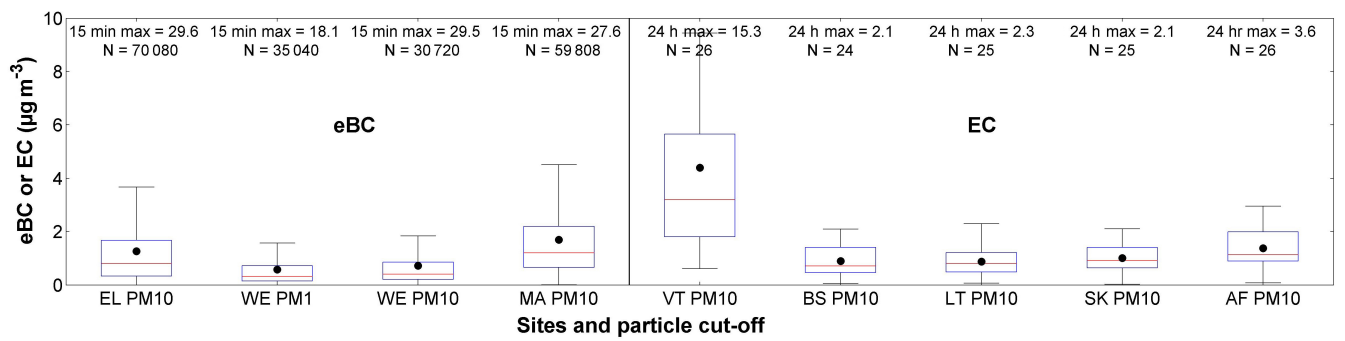

Figure 4. Box-and-whisker plot indicating statistical eBC mass concentrations at the Elandsfontein (EL), Welgegund (WE) and Marikana (MA) sites, as well as EC mass concentrations at the Vaal Triangle (VT), Botsalano (BS), Louis Trichardt (LT), Skukuza (SK) and Amersfoort (AF) sites. The red line of each box indicates the median, the black dot the mean, the top and bottom edges of the box the 25th and 75 th percentiles and the whiskers $\pm 2.7 \sigma$ (99.3\% coverage if the data have a normal distribution). The 15 min and $24 \mathrm{~h}$ maximum mass concentration values measured at the sites with continuous and offline analyses, respectively, as well as the number of measurements $(N)$, are indicated.

$0.3 \mu \mathrm{g} \mathrm{m}^{-3}$ have been reported for western parts of northern Europe (e.g. Yttri et al., 2007). At natural and rural European background sites, values of 0.3 to 0.5 and 0.6 to $1.6 \mu \mathrm{g} \mathrm{m} \mathrm{m}^{-3}$ have been reported, respectively (e.g. Putaud et al., 2004; Hyvärinen et al., 2011). The other South African background sites reported here, i.e. Botsalano, Louis Trichardt and Skukuza, had higher mean and median values than the aforementioned European background/natural sites. The industrial/urban/household affected sites reported here, i.e. Elandsfontein, Marikana, Vaal Triangle and Amersfoort, had higher average $\mathrm{eBC}$ or EC mass concentration levels than, for instance, an urban site in a large European city, where $\mathrm{BC}$ mass concentrations had an average of approximately $1.0 \mu \mathrm{g} \mathrm{m}^{-3}$ (Järvi et al., 2008; Viidanoja et al., 2002). In general, it can therefore be stated that $\mathrm{eBC}$ or EC mass concentrations across the measurement area considered are relatively high.
Apart from the spatial information and possible indication of contributing sources obtained from Fig. 4, it is also evident from the comparison of the $\mathrm{PM}_{1}$ and $\mathrm{PM}_{10}$ eBC data of Welgegund that most of the eBC resides in the $\mathrm{PM}_{1}$ size fraction, which was expected.

\subsection{Temporal variations}

\subsubsection{Seasonal variations}

In order to determine seasonal patterns, only the site where continuous measurements were conducted was considered. Monthly statistical distributions of eBC mass concentrations for Elandsfontein, Welgegund and Marikana measurement sites are presented in Fig. 5. As is evident from these figures, there is a distinct and similar seasonal pattern observed at all three sites, with the highest $\mathrm{eBC}$ mass concentrations measured from June to October. These months coincide with the colder winter months of June to August, as well as the 

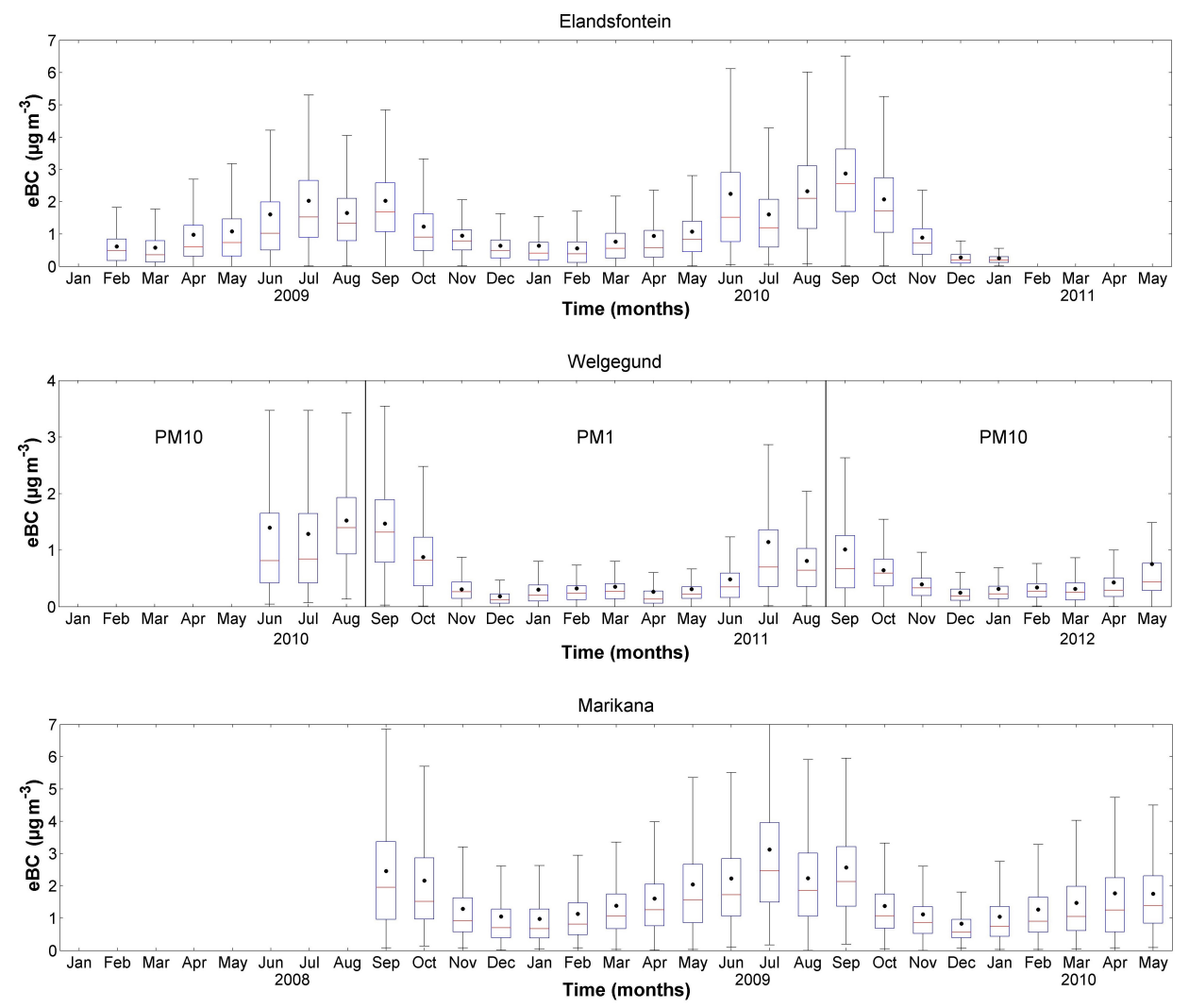

Figure 5. Monthly statistical distribution of eBC concentrations at the three sites where continuous measurement data were gathered, i.e. Elandsfontein, Welgegund and Marikana. $\mathrm{PM}_{10}$ inlets were used at Elandsfontein and Marikana, while measurements at Welgegund were conducted with either a $\mathrm{PM}_{1}$ or $\mathrm{PM}_{10}$ inlet. The red line of each box is the median, the black dots indicate the mean, the top and bottom edges of the box are the 25th and 75th percentiles and the whiskers $\pm 2.7 \sigma$ (99.3\% coverage if the data have a normal distribution).

dry season on the South African Highveld occurring between May and mid-October. Venter et al. (2012) previously indicated that household combustion for cooking and space heating in informal and semiformal settlements during winter could be a significant eBC mass concentration source on a local scale. However, it has not yet been determined whether such household combustion could also make a significant regional contribution in South Africa. During the dry season, increased savannah and grassland wild fires occur, which contributed to increased atmospheric eBC concentrations (Bond et al., 2004; Saha and Despiau, 2009). The influence of both of these potential eBC sources, i.e. household combustion and wild fires, will be discussed later in Sect. 3.3. Obviously, increased atmospheric stability during the colder months (Garstang et al., 1996) will also lead to trapping of low-level emissions, hence resulting in possible higher eBC concentrations. This is discussed in greater detail in the next section.

\subsubsection{Diurnal variations}

Average diurnal plots as well as average seasonal diurnal plots (separate for summer, autumn, winter and spring) for the stations where continuous eBC mass concentration data were gathered, i.e. Elandsfontein, Marikana and Welgegund (both $\mathrm{PM}_{1}$ and $\mathrm{PM}_{10}$ ), are presented in Fig. 6 .

The Elandsfontein diurnal plots indicate that the main source of $\mathrm{eBC}$ is not high stack emissions. The area in which Elandsfontein is situated is a well-known international $\mathrm{NO}_{2}$ hotspot, with tropospheric column densities similar to what is observed over southeast Asia (Lourens et al., 2012, 2016). It is widely accepted that $\mathrm{NO}_{2}$ in this hotspot mainly originates from $\mathrm{NO}_{x}$ emission from coal-fired power stations. The troposphere over the Highveld is strongly layered, with several inversion layers occurring. These layers prevent vertical mixing to a large degree (Garstang et al., 1996). The aforementioned $\mathrm{NO}_{x}$ emissions are released into the atmosphere via high stacks, which are typically taller than $300 \mathrm{~m}$. The effective stack heights (actual stack heights plus rise due to emissions being hot) were designed to ensure that the $\mathrm{NO}_{x}$ emissions are released above the lowest inversion layers to prevent excessive local pollution and ensure distribution over a wider area. Collet et al. (2010) proved that $\mathrm{NO}_{2}$ concentrations at Elandsfontein peak after 11:00 LT due to the breakdown of the lowest inversion layers, which allow downward mixing of the $\mathrm{NO}_{x}$ tall stack emissions. Therefore, if eBC 

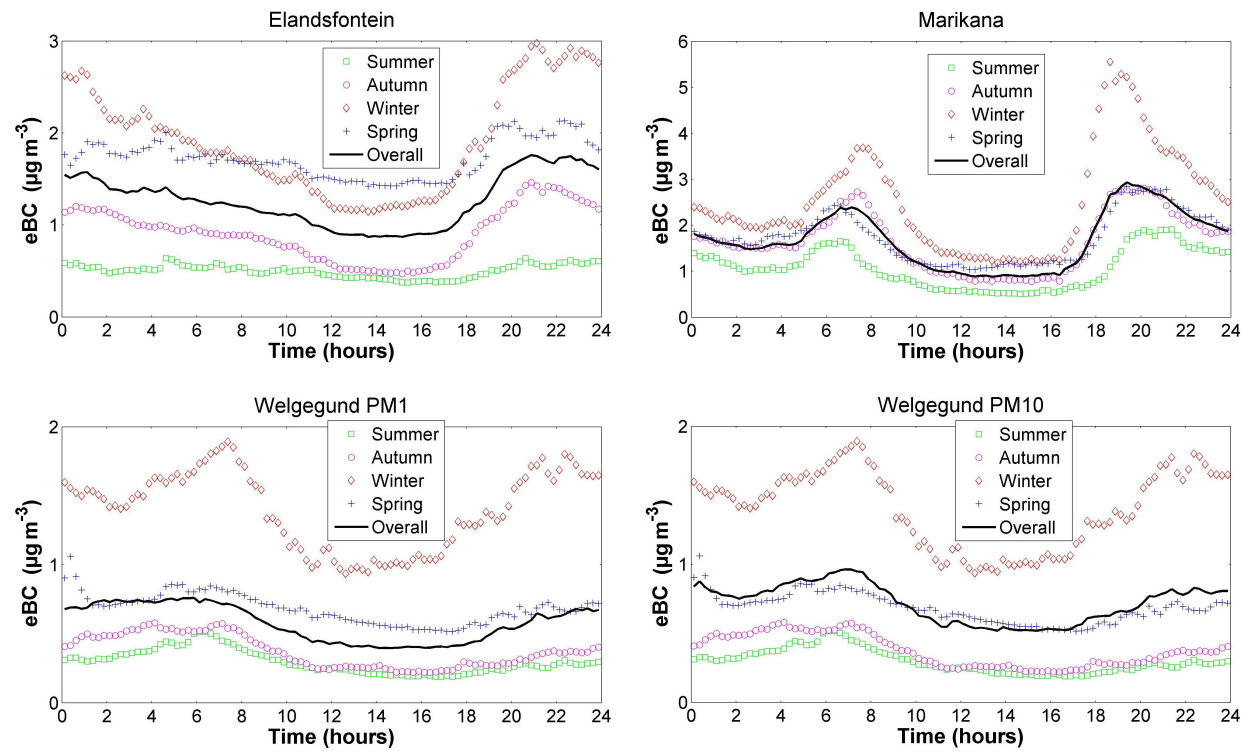

Figure 6. Overall (all the data) and seasonal (each season separately) average eBC diurnal patterns observed for Elandsfontein, Welgegund and Marikana. Summer: DJF, Autumn: MAM, Winter: JJA and Spring: SON.

mainly originated from these large point sources with tall stacks, eBC concentrations would also have peaked after the breakdown of the nighttime inversion layers that would allow downward mixing of tall-stack-emitted eBC. However, this is clearly not the case. Additionally, the winter diurnal plot for Elandsfontein indicates substantially higher values during nighttime when the planetary boundary layer (PBL) is less well mixed (i.e. strong low-level inversion layers that trap surface emissions), which re-enforces the notion that the major origin of $\mathrm{eBC}$ is from low-level sources, rather than industrial high stacks. At Elandsfontein, the daily evolution of the PBL starts approximately 3-4 h after sunrise (varies between 05:07 and 06:56 LT), which results in increasing atmospheric mixing down from the upper troposphere, including high stack emissions (Korhonen et al., 2014). Considering all the aforementioned information, the most likely eBC sources during winter (June to August) and the dry season (May to mid-October) are surface emissions from household combustion as well as savannah and grassland fires. This is an important finding since industries on the Mpumalanga Highveld are often blamed for all forms of pollution due to the $\mathrm{NO}_{2}$ hotspot over this area.

In contrast to Elandsfontein, eBC concentrations at Marikana peaked in the early mornings (05:00-09:00 LT) and again in the early to late evenings (17:30-22:00 LT). These times correlate with the peak times for household combustion for space heating and cooking in the nearby informal and semiformal settlements (Venter et al., 2012). Seasonal timing of the peak eBC concentration in the diurnal plots confirms that household combustion is the main source at this site. In winter, during which time daylight hours are shorter, the peak morning $\mathrm{eBC}$ concentration is at $\sim 07: 00 \mathrm{LT}$ and the evening peak at $\sim 18: 00 \mathrm{LT}$, whereas, during summer, with longer daylight hours, the peak morning eBC concentration is at $\sim 06: 00 \mathrm{LT}$ and the evening peak at $\sim 20: 00 \mathrm{LT}$. During the cold winter months, space heating is a priority, apart from cooking, while in summer, household combustion would mainly be used for cooking. These seasonal household combustion use patterns are reflected by the diurnal eBC patterns for Marikana.

The eBC diurnal plots of Welgegund do not indicate welldefined peaks as observed for Marikana. This is expected since there are no semiformal or informal settlements located close to the Welgegund station. Additionally, there are also no large point sources close to Welgegund, as there are at Elandsfontein. Therefore, only sources that have a regional influence are likely to affect eBC levels at Welgegund. It is therefore likely that savannah and grassland fires, especially in the winter and early spring, are mainly responsible for eBC levels measured at Welgegund and mainly long-range transportation during the wet season. The lower PBL during the evenings and early mornings will concentrate the eBC and contribute to $\mathrm{eBC}$ levels rising in the evening and only decreasing $3-4 \mathrm{~h}$ after sunrise, as suggested by Korhonen et al. (2014). This effect is strongest in the winter months.

\section{3 eBC source identification}

\subsubsection{General}

As has already been indicated, there are various possible sources for eBC, e.g. industrial, household combustion, traffic and savannah and grassland fires. In this section, possible significant contributing sources are considered further. Fig- 


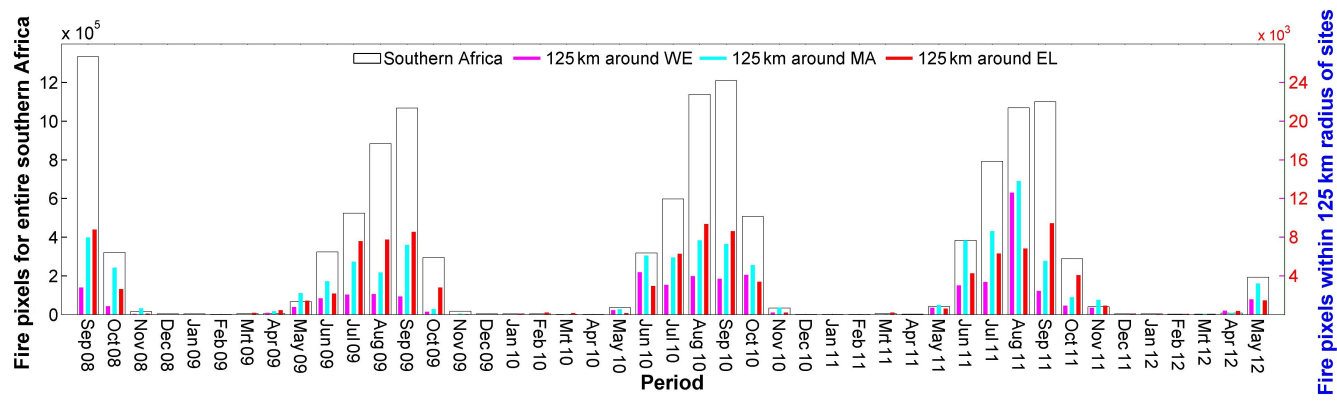

Figure 7. Fire pixels within the entire southern Africa domain $\left(10-35^{\circ} \mathrm{S}\right.$, and $\left.10-41^{\circ} \mathrm{E}\right)$ indicated on the primary $y$ axis, as well as fires pixels within a radius of $125 \mathrm{~km}$ around Elandsfontein (EL), Marikana (MA) and Welgegund (WE) measurement sites indicated on the secondary $y$ axis, as determined from the MODIS collection 5 burned area product (Roy et al., 2008).

ure 7 indicates the fire pixel counts calculated from MODIS (collection 5 burned area product) (Roy et al., 2008) within the entire domain of southern Africa $\left(10-35^{\circ} \mathrm{S}\right.$, and 10 $41^{\circ} \mathrm{E}$ ) indicated on the primary $y$ axis, as well as fire pixel counts within a radius of $125 \mathrm{~km}$ around measurement sites where high-resolution $\mathrm{eBC}$ data were gathered on the secondary $y$ axis.

It is important to note that it is difficult to separate the influence of various sources at a specific site, since the measured $\mathrm{eBC}$ originates from a mixture of contributing sources. Therefore, Fig. 7 was considered first, since it provided guidance about which periods would be best to consider for the different sources. For instance, there are very few savannah and grassland fires from December to February every year in the northern interior of South Africa. The savannah and grassland fires that do occur during this period occur in the southern Western Cape, which will not influence eBC levels in the northern interior significantly. In addition, minimal household combustion for space heating takes place in December to February, since these are the warmest months. During this time, household combustion for cooking will still take place, but such daily emission periods are far shorter than the extended space heating period (typically early evening, throughout the night, until after sunrise the next day) occurring during the colder months. Considering the aforementioned information, it is best to isolate industrial and traffic related eBC sources from December to February.

It is clear from the overall southern African fire frequencies, as well as those around each site (Fig. 7), that August and September have the highest savannah and grassland fire intensities. This is the driest period, just before the onset of the first rains, usually in mid-October. We can therefore isolate savannah and grassland fires best in this period, since their effect is strongest. The influence of household combustion is also not that strong in this period, since it is already becoming warmer, and therefore less space heating is required. By considering aerosol particle concentrations at Marikana, Vakkari et al. (2013) proved that the evening peak associ- ated with household combustion was significantly lower in September than from June to July.

Since it is coldest in June and July, the effect of household combustion for space heating is at its strongest, making the isolation of the household combustion effect better during these months.

In the following sections, $\mathrm{eBC}$ contributions from the above-mentioned sources, i.e. industrial, traffic, savannah and grassland fires, and household combustion, will be explored in greater detail for the Elandsfontein site only. This site was chosen since it can be affected by all the aforementioned sources, while the other sites where continuous highresolution data were gathered will mainly be influenced by savannah and grassland fires (Welgegund) or household combustion (Marikana).

\subsubsection{Industrial contribution to $\mathrm{eBC}$ at Elandsfontein}

Numerous large industrial point sources linked to coal utilisation occur in the South African interior, e.g. coal-fired power stations that produce most of South Africa's electricity, large petrochemical operations utilising coal gasification and numerous pyrometallurgical smelters utilising coal and coal-related products as carbonaceous reductants for the production of various steels and alloys (Collet et al., 2010; Lourens et al., 2011; Beukes et al., 2012). However, the possible contributions of these large point sources to atmospheric $\mathrm{BC}$ have not yet been investigated.

In Fig. 8, eBC concentrations measured at Elandsfontein were plotted against the shortest distances by which back trajectories had passed any large point source during the summer months (December to February) when minimal household combustion, as well as savannah and grassland fires, occur. Although there was no clear correlation (Fig. 8), the results indicated that at least some trajectories passing closer to these large industrial point sources had higher eBC concentrations. This suggests that $\mathrm{eBC}$ contributions from large industrial point sources cannot be ignored, notwithstanding the diurnal patterns, indicating that high stack industrial emissions were not the main source (Fig. 6). 


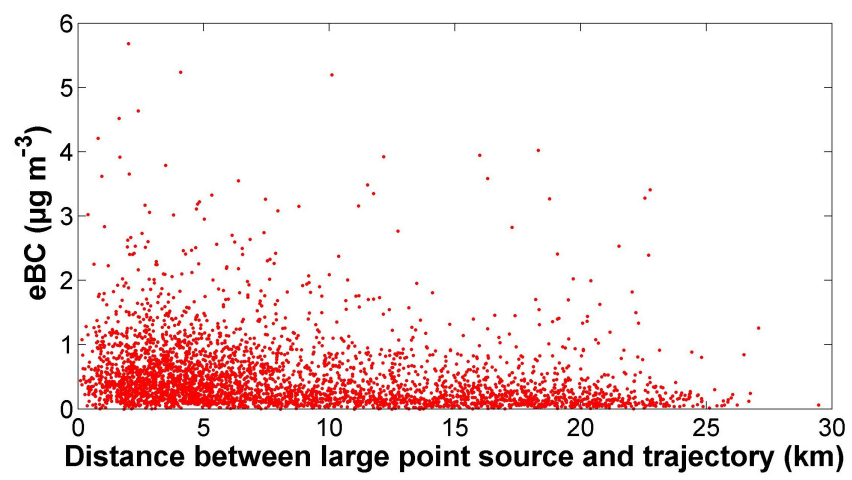

Figure 8. Hourly average eBC concentrations plotted against the shortest distances that hourly arriving back trajectories had passed large point sources during the summer months, i.e. December to February, at Elandsfontein.

Although it was indicated in Sect. 3.2.2 that it was unlikely that high stack emissions were the main source of eBC at Elandsfontein, the possible fractional contributions of industries still need to be assessed. In order to quantify this, eBC peaks that coincided with peaks of other pollutants, which are characteristic of large point sources in that area, were considered for the December to February period. Two distinct types of contributing sources were identified, i.e. eBC peaks that coincided with $\mathrm{SO}_{2}, \mathrm{NO}_{2}$ and $\mathrm{NO}$, as well as eBC peaks that only coincided with $\mathrm{H}_{2} \mathrm{~S}$. From the literature, it is known that plumes from coal-fired power plants on the South African Highveld are characterised by coincidental $\mathrm{SO}_{2}, \mathrm{NO}_{2}$ and $\mathrm{NO}$ increases (Collet et al., 2010; Lourens et al., 2011). Although it is not shown here, eBC plumes that were associated with these species were confirmed to have originated from coal-fired power stations with backtrajectory analyses. However, $\mathrm{H}_{2} \mathrm{~S}$ peaks that coincided with the eBC peaks could have been from various sources, e.g. the large petrochemical plant near Secunda, pyrometallurgical smelters in the area or smouldering coal dumps that burn as a result of spontaneous combustion. In order to identify the origin of the eBC peaks that were associated with $\mathrm{H}_{2} \mathrm{~S}$ only, a map on which all back trajectories that arrived at Elandsfontein during these $\mathrm{eBC}$ peaks (coincidental increases in eBC and $\mathrm{H}_{2} \mathrm{~S}$ ) were plotted is presented in Fig. 9, together with a wind rose for such events. From these figures, it is evident that the back trajectories that were associated with simultaneous $\mathrm{eBC}$ and $\mathrm{H}_{2} \mathrm{~S}$ concentration peaks only passed over the sector between the northwest and northeast from Elandsfontein. This is the area where all the pyrometallurgical smelters are located. Smouldering coal dumps occur in all directions from Elandsfontein. Additionally, no trajectories associated with coincidental $\mathrm{eBC}$ and $\mathrm{H}_{2} \mathrm{~S}$ increases had passed over the petrochemical operation. It therefore seems likely that the eBC contribution associated with $\mathrm{H}_{2} \mathrm{~S}$ originates from the pyrometallurgical smelters in the sector located between northwest and northeast from Elandsfontein. (a)

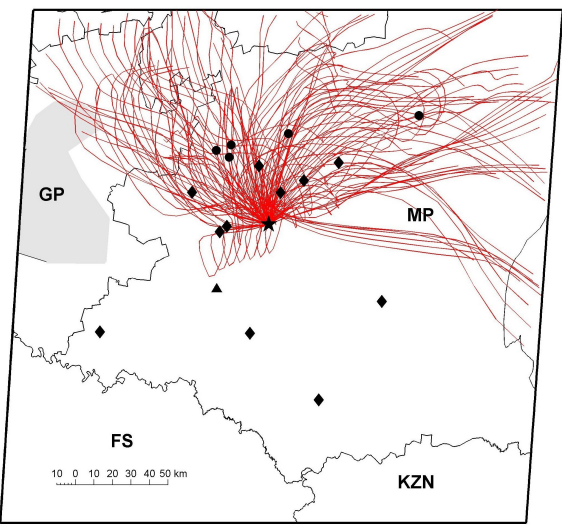

(b)

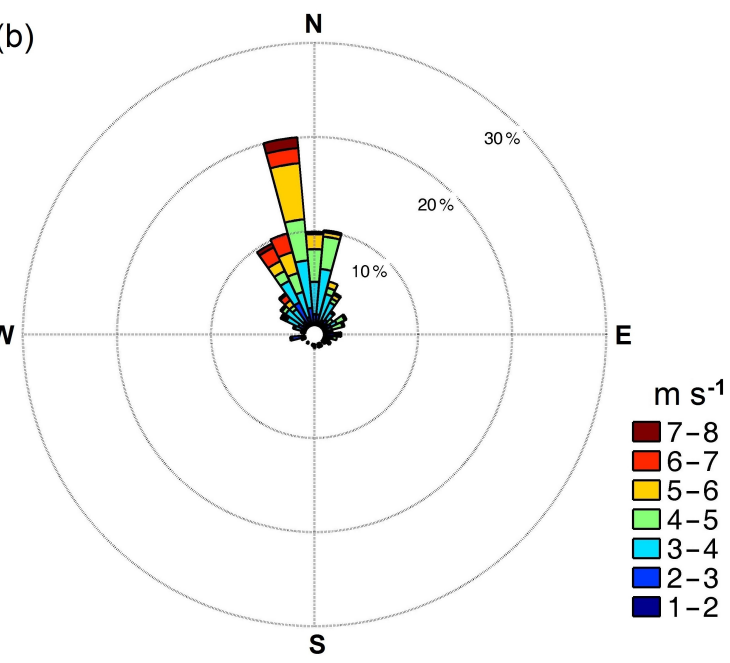

Figure 9. (a) All $24 \mathrm{~h}$ back trajectories associated with peaks characterised by coincidental increases in $\mathrm{eBC}$ and $\mathrm{H}_{2} \mathrm{~S}$ from December to February. The Elandsfontein site is indicated by the black star. The black dots indicate pyrometallurgical smelters and char plants, the black diamonds coal-fired power plants and the black triangle a large petrochemical operation. (b) Wind rose showing the prevailing wind direction during periods when $\mathrm{eBC}$ plumes that coincided with $\mathrm{H}_{2} \mathrm{~S}$ plumes were observed.

\subsubsection{Traffic contribution to $\mathrm{eBC}$ at Elandsfontein}

From the literature, it seems feasible to associate increased BC concentrations with traffic emissions, particularly dieselpowered vehicles (Cachier, 1995; Cooke and Wilson, 1996; Bond and Sun, 2005). The Mpumalanga Highveld around Elandsfontein is the area where most thermal coal is mined in South Africa, which is mostly transported by diesel trucks via various roads criss-crossing the area, as indicated in Fig. 10a. However, the closest tarred road, i.e. the R35, passes Elandsfontein approximately $4.7 \mathrm{~km}$ to the east. This road is also one of the most utilised for coal road transportation. Additionally, to the north of Elandsfontein, numerous such tarred roads are located; e.g. the national N12 and N4 highways pass Elandsfontein approximately $38 \mathrm{~km}$ to the north and northwest. It therefore seems reasonable that the traffic- 
(a)

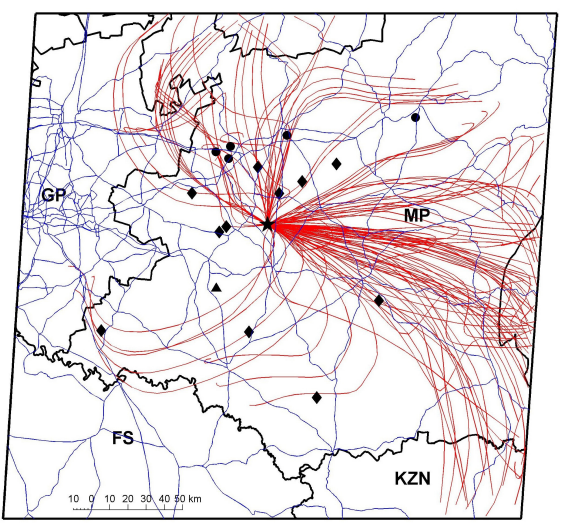

(b)

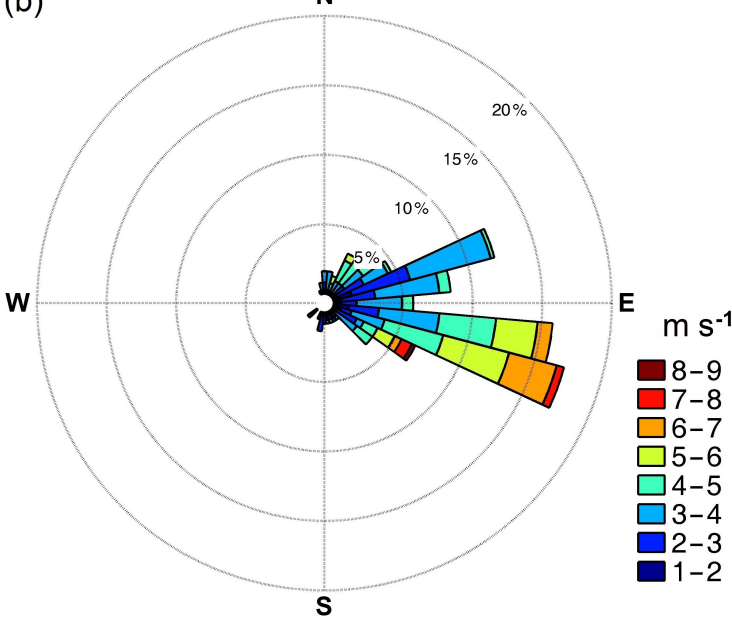

Figure 10. (a) All $24 \mathrm{~h}$ back trajectories associated with peaks characterised by coincidental increases in $\mathrm{eBC}$ and $\mathrm{NO}_{2}$ from December to February. The Elandsfontein site is indicated by the black star. The black dots indicate pyrometallurgical smelters and char plants, the black diamonds indicate coal-fired power plants and the black triangle a large petrochemical operation. Roads are indicated with blue lines. (b) Wind rose showing the prevailing wind direction during periods when eBC plumes that coincided with $\mathrm{NO}_{2}$ plumes were observed.

related eBC back-trajectory map (Fig. 10a, which was for coincidental increases in $\mathrm{eBC}$ and $\mathrm{NO}_{2}$ time periods only) is somewhat biased toward the east and north, although limited contributions from other sectors are also evident. The wind rose showing the prevailing wind direction during periods when eBC plumes that coincided with $\mathrm{NO}_{2}$ plumes were observed (Fig. 10b) also indicates the sources to be mainly from the east, i.e. where the R35 passes Elandsfontein.

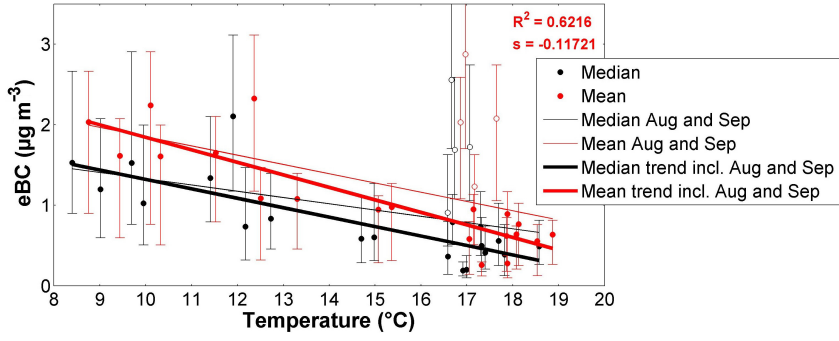

Figure 11. Monthly median and mean eBC (with bars indicating 25th and 75th percentiles) plotted against monthly median and mean temperatures for Elandsfontein.

\subsubsection{Household combustion contribution to $\mathrm{eBC}$ at Elandsfontein}

Venter et al. (2012) indicated that household combustion for space heating and cooking in informal and semiformal settlements contributes significantly to poor air quality in such settlements. In Fig. 11, the relationships between monthly average and median $\mathrm{eBC}$, against monthly mean and median temperatures for Elandsfontein, are presented. As is evident from the results presented in Fig. 11, there is a significant correlation between $\mathrm{eBC}$ concentration and temperature if August and September are ignored (indicated with hollow markers in Fig. 11). During these months, significant eBC contributions can be expected from savannah and grassland fires (see Fig. 7). The correlation between eBC concentration and temperature indicates that household combustion for space heating contributes significantly to eBC levels measured at Elandsfontein, especially during the colder months when household combustion is used more frequently for space heating.

Similar to the analysis performed for the large industrial point sources (Fig. 8), eBC concentrations were drawn as a function of the closest distance that back trajectories had passed informal and semiformal settlements for Elandsfontein. However, this was done only for the winter months of June and July for both years, since household combustion contributions could then be better isolated from savannah and grassland fire contributions during these periods. These results are presented in Fig. 12. Although not conclusive, the results presented indicate that, in general, higher eBC concentrations were observed when trajectories passed closer to informal and semiformal settlements in June and July.

Household combustion results in the emission of a number of different species (Venter et al., 2012). In this work, tracers for household combustion were determined from species that simultaneously increased with eBC, including $\mathrm{NO}_{2}, \mathrm{SO}_{2}$ and $\mathrm{H}_{2} \mathrm{~S}$ but not NO. Low-grade coal that is burned in ineffective stoves is commonly used for household combustion in the Mpumalanga Highveld, due to such coal being relative inexpensive. The use of this results in $\mathrm{NO}_{x}, \mathrm{SO}_{2}$ and $\mathrm{H}_{2} \mathrm{~S}$ emissions. During the cold winter months of June and 


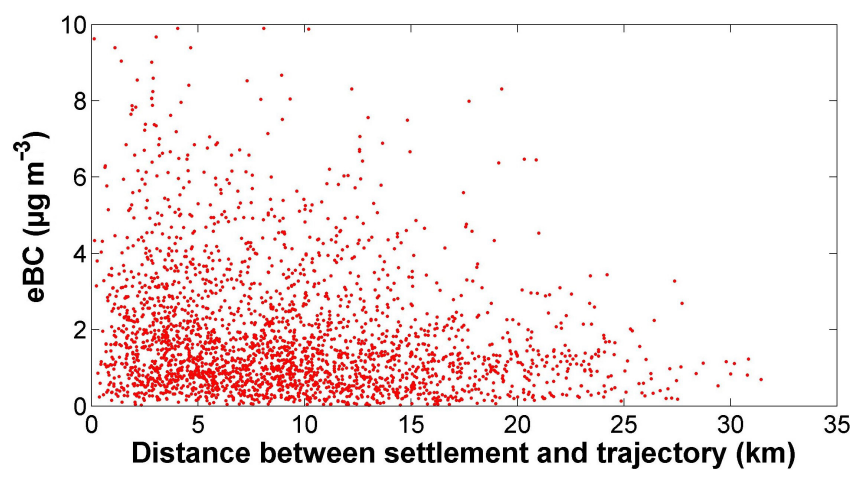

Figure 12. eBC concentration plotted against the shortest distances that hourly arriving back trajectories had passed informal or semiformal settlements during the winter months of June and July at Elandsfontein.

July, strong inversion layers trap pollutants emitted closer to ground level and prevent the mixing and subsequent transportation of these pollutants. The low-level emissions from informal and semiformal settlements are therefore not dispersed before the inversion layers break up mid-morning. A previous study has indicated that the PBL starts growing around 10:00 LT at Elandsfontein during the winter months (Korhonen et al., 2014). It can therefore be accepted that the low-level inversion layers also start dissipating at that time. The long residence time of air masses around informal and semiformal settlements in winter before being dispersed, as well as additional transport time, results in NO being oxidised to $\mathrm{NO}_{2}$ prior to these plumes being measured at Elandsfontein.

Figure 13a indicates back trajectories associated with household combustion contribution to $\mathrm{eBC}$ levels (for time periods with coincidental increases in eBC with $\mathrm{NO}_{2}, \mathrm{SO}_{2}$ and $\mathrm{H}_{2} \mathrm{~S}$ but not $\mathrm{NO}$ ). Most of these back trajectories passed over the Thubelihle and Kriel settlements, which are located 12.4 and $13.8 \mathrm{~km}$ from Elandsfontein, respectively. Apart from this relatively local $\mathrm{eBC}$ influence from household combustion, most trajectories associated with household combustion $\mathrm{eBC}$ plumes passed over the sector between east and north-northeast, where the cities of Witbank and Middelburg, as well as the Johannesburg-Pretoria megacity, are located. These larger cities have many more large informal and semiformal settlements associated with them than the smaller towns in the area do. The wind rose showing the prevailing wind direction during periods when $\mathrm{eBC}$ plumes that coincided with $\mathrm{NO}_{2}, \mathrm{SO}_{2}$ and $\mathrm{H}_{2} \mathrm{~S}$ plumes were observed (Fig. 13b) also indicates the sources to be mainly from more or less the same direction as most of the back trajectories.

\subsubsection{Savannah and grassland fire contribution to eBC at Elandsfontein}

Vakkari et al. (2014) relatively recently indicated how savannah and grassland fire emission aerosols are changed via at- (a)

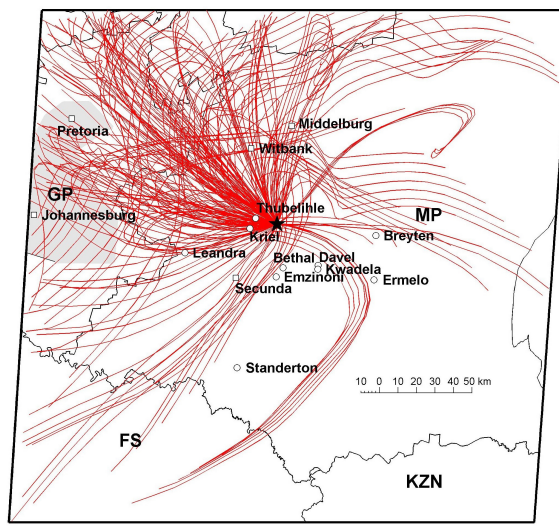

(b)

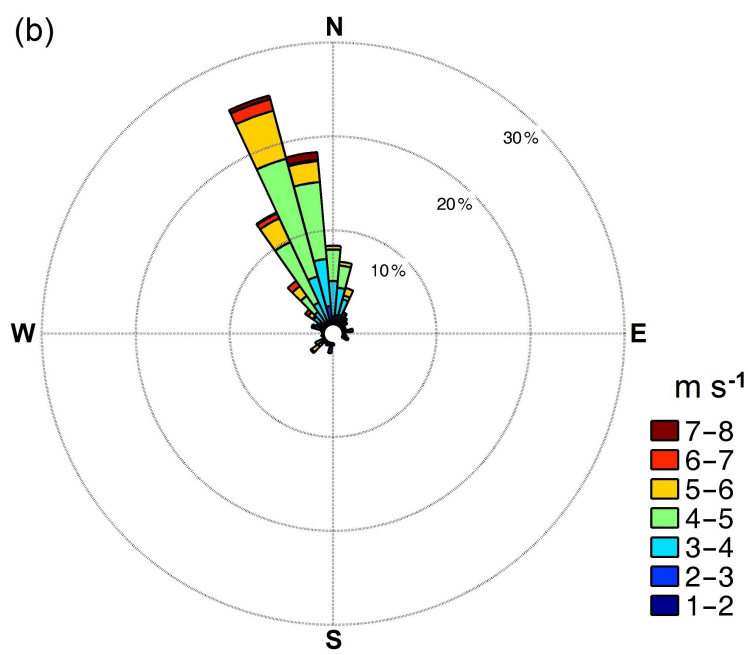

Figure 13. (a) Map indicating $24 \mathrm{~h}$ back trajectories associated with peaks characterised by coincidental increases in eBC with $\mathrm{NO}_{2}$, $\mathrm{SO}_{2}$ and $\mathrm{H}_{2} \mathrm{~S}$ but not $\mathrm{NO}$ in June and July. The Elandsfontein site is indicated by the black star. (b) The wind rose associated with arrival times of plumes associated with household combustion is indicated in panel (b).

mospheric oxidation in South Africa. To positively identify savannah and grassland fire plumes, the aforementioned authors used $\mathrm{CO}$ and $\mathrm{eBC}$ as coincidental increasing species. However, $\mathrm{CO}$ was not measured at Elandsfontein, and therefore the positive identification of savannah and grassland plumes could not be undertaken using this method. Additionally, the plumes of savannah and grassland fires occurring in neighbouring countries arriving at Elandsfontein will be diluted and aged. Such regional fires lift the entire eBC baseline, rather than exhibiting well-defined plumes that can be separated from the baseline (Mafusire et al., 2016), as was done for the industrial, traffic and household combustion sources. Thus far in the paper, we have considered August and September as the months in which savannah and grassland fire frequencies peak. However, some household combustion might still occur in August. Therefore, to determine the overall baseline increase as a result of savannah and grassland fires, only September was considered as being rep- 


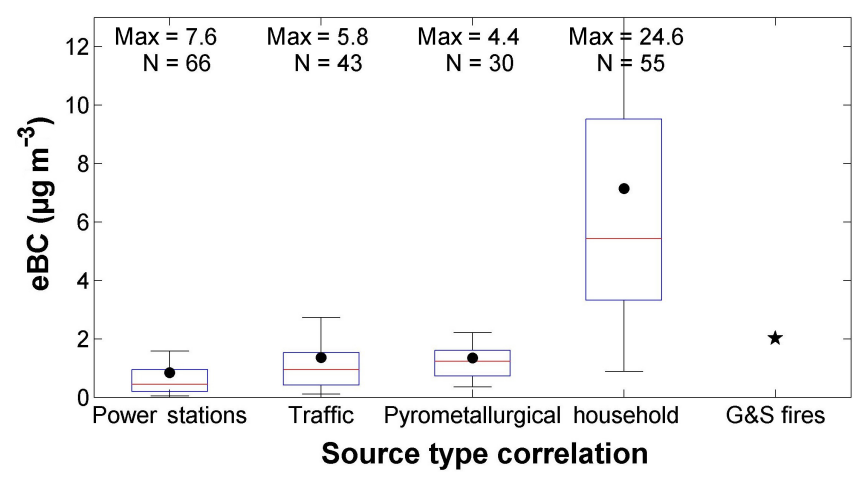

Figure 14. $\triangle \mathrm{eBC}$ measured during plumes when eBC increases originated from coal-fired power stations, traffic, pyrometallurgical smelters and household combustion as measured at Elandsfontein. The overall mean baseline increase due to savannah and grassland fires (G\&S fires) in September is also indicated. These data were normalised to variations in boundary layer at Elandsfontein (Korhonen et al., 2014).

resentative of savannah and grassland fires, while the summer months (December to February) can be considered as the baseline. By subtracting the September eBC mean from the summer mean, the eBC baseline increased by $2.01 \mu \mathrm{g} \mathrm{m}^{-3}$. This increase will be contextualised with the previously investigated sources in the next section.

\subsubsection{Contextualisation of eBC source strengths at Elandsfontein}

Up to now, the individual eBC sources for Elandsfontein were discussed, but their strengths were not compared with one another. In Fig. 14, the comparison of the $\triangle \mathrm{eBC}$ from coal-fired power stations, pyrometallurgical smelters, traffic, household combustion, as well as savannah and grassland fires for Elandsfontein is presented. The relative savannah and grassland fire source strength is not statistically presented with a box and whisker like the other sources but only with a black star that indicates the mean eBC baseline increase during September if compared to the summer months of December to February. The data presented in Fig. 14 were normalised to account for variations in PBL height at Elandsfontein. This was done by using the monthly average PBL daily maximum heights reported by Korhonen et al. (2014) for 2010 at Elandsfontein. Unfortunately, no such data existed for 2009; therefore, the 2009 monthly PBL heights were assumed to be similar to 2010. Thereafter, the ratios of the average PBL daily maximum heights for each of the periods during which certain sources could be better isolated (i.e. December to February for large point sources and traffic emission; June to July for household combustion) were calculated and compared to the average PBL daily maximum heights for August and September (period with peak savannah and grassland fire occurrence). The $\triangle \mathrm{eBC}$ for each of the sources identified in the December to February as well as
June to July periods were then adjusted with these ratios to account for variations in the PBL, which could have a significant dilution or concentration effect on the measured $\mathrm{eBC}$ values from which the $\triangle \mathrm{eBCs}$ were derived. The results indicate the significant source strength of household combustion, as well as savannah and grassland fires, as measured at Elandsfontein. However, coal-fired power stations, pyrometallurgical and/or char plants and traffic contribute year round, while household combustion, as well as savannah and grassland fires only contribute significantly in May to August and June to September, respectively. Bond et al. (2013) indicated relatively high $\mathrm{BC}$ emissions from biofuel cooking (calculated for Africa in total) but did not indicate space heating to contribute significantly. However, our data seem to prove that space heating does contribute meaningfully to eBC levels in South Africa during the colder winter months (June-July).

Vakkari et al. (2014) used $\triangle \mathrm{eBC}$ in relation to other species to characterise differences in plumes of savannah and grassland fires. In a similar manner, these ratios for $\triangle \mathrm{eBC}$ divided by species that were characteristic of the different plume types identified (i.e. representing industrial, traffic or house hold combustion) were determined and are presented in Fig. 15. Since so little BC data are available for South Africa, the median and/or mean values indicated in this figure could be used in subsequent modelling studies as emission factors to estimate $\mathrm{eBC}$ if only the concentration(s) of the species that were used in calculating these ratios are known.

\subsection{Mathematical confirmation of eBC sources at Elandsfontein}

Four scenarios were investigated with MLR analyses. Firstly, MLR analysis was conducted for the entire monitoring period at Elandsfontein. As is evident from the top left panel in Fig. 16, the RMSE difference between the actual measured eBC concentration and the calculated eBC concentrations, if only one independent parameter was included in the optimum MLR solution, was approximately 1.54 . The RMSE difference could be reduced by including more independent parameters in the optimum MLR solution. However, it was found that the inclusion of more than nine independent parameters did not further reduce the RMSE difference significantly.

From the MLR analysis conducted for the entire measurement period at Elandsfontein, the actual MLR equation could be obtained, which is presented as Eq. (2). With this equation, eBC at Elandsfontein could be calculated. The comparisons between actual and calculated (with Eq. 2) eBC concentrations are presented in Fig. 17. From this comparison, it is evident that Eq. (2) could be used to calculate eBC at Elandsfontein relatively accurately. 


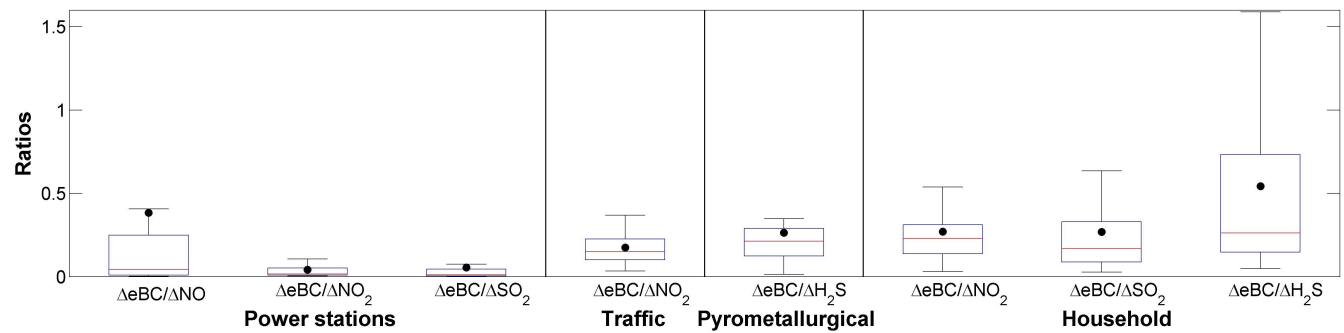

Figure 15. Ratio of $\triangle \mathrm{eBC}$ divided by $\Delta$ of other species relevant to the identification of each source type, except for grassland and savannah fires measured at Elandsfontein.
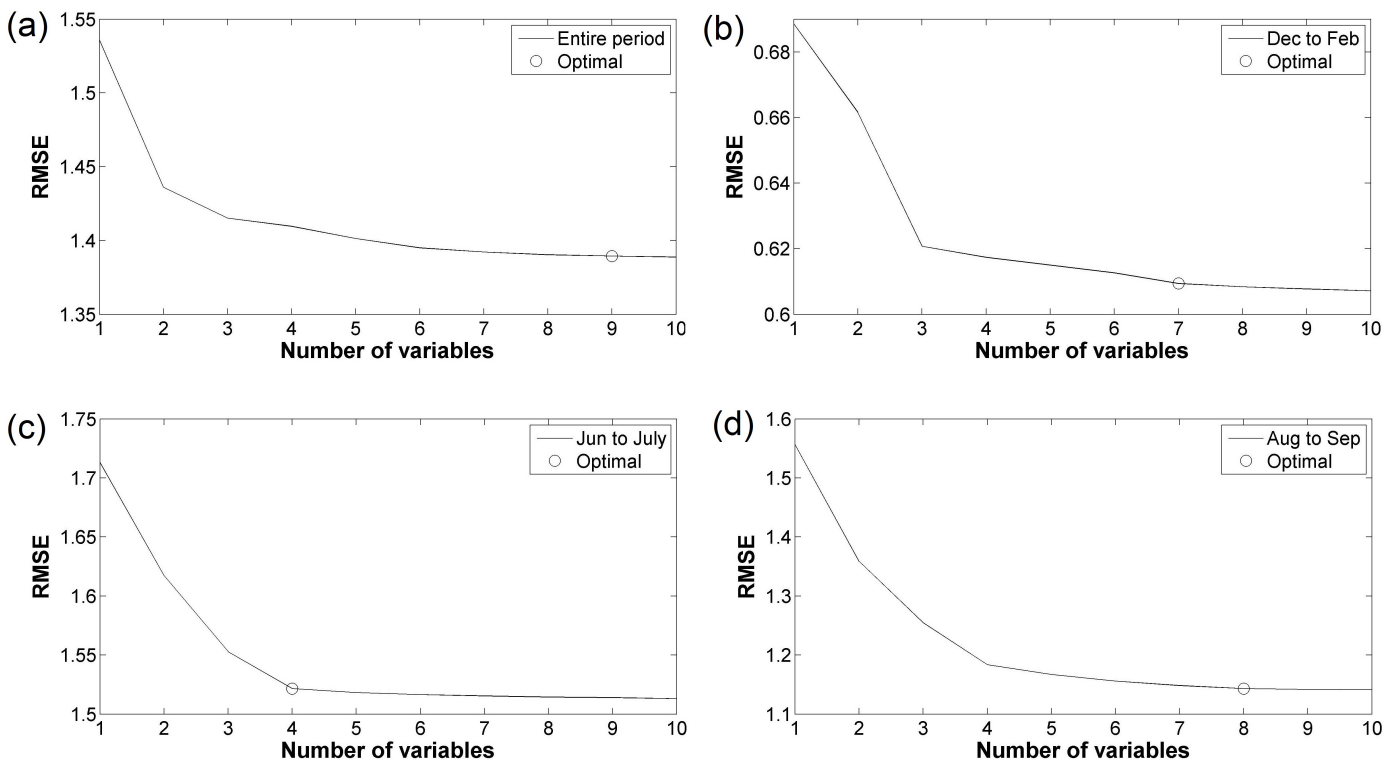

Figure 16. RMSE difference between the MLR calculated eBC and the actual measured eBC at Elandsfontein for the entire measurement period (a), as well as the December to February (b), June to July (c) and August to September (d) periods individually.

$$
\begin{aligned}
y & =-33.7038+\left(0.0050 \times \mathrm{O}_{3}\right)+\left(0.0387 \times \mathrm{SO}_{2}\right) \\
& +\left(0.0006 \times \mathrm{NO}_{2}\right)+\left(0.0722 \times \mathrm{H}_{2} \mathrm{~S}\right)+(-0.0174 \times \mathrm{RH}) \\
& +(0.0997 \times \mathrm{WS})+(0.0005 \times \mathrm{WD})+(0.0421 \times \mathrm{P}) \\
& +(2.27433 \times \mathrm{T}-\mathrm{grad})
\end{aligned}
$$

In order to use MLR to verify whether the eBC contribution sources were identified correctly in Sect. 3.3, MLR analyses were also conducted for the different time periods defined for isolation of the various sources, i.e. December to February for industrial and traffic sources, June and July for household combustion, and August and September for savannah and grassland fires.

As is indicated in Eq. (3) and the top right panel of Fig. 16, the optimum MLR solution obtained for the December to February period included seven independent variables in the equation. Firstly, the fact that fewer independent variables were required to reduce the RMSE optimally, if compared with the overall period (top left panel of Fig. 16), indicates that the December to February period is influenced by fewer sources. Secondly, the identity of the independent variables and the sign (positive or negative) associated with them in Eq. (3) are noteworthy. Increased $\mathrm{O}_{3}$ concentrations led to lower $\mathrm{eBC}$, which indicates that aged air masses had lower eBC than fresh plumes do. This supports the notion that relatively nearby industry and traffic sources dominate. The increased eBC, associated with increased $\mathrm{NO}_{2}$ and $\mathrm{H}_{2} \mathrm{~S}$ concentrations in Eq. (3), supports the identity of the specific source types previously identified, i.e. coal-fired power stations, pyrometallurgical smelters, as well as traffic emissions. The remaining independent variables in Eq. (3) are associated with meteorological parameters, which could indicate that meteorological patterns (e.g. atmospheric stability as indicated by $\mathrm{T}$ gradient) could have a significant influence on 


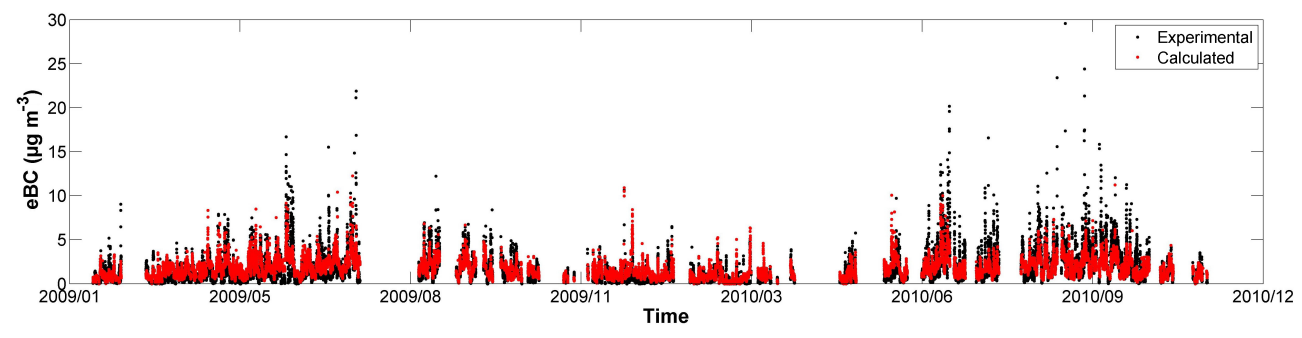

Figure 17. Actual eBC compared with calculated eBC (using Eq. 2) for the entire monitoring period at Elandsfontein.

plumes containing eBC measured at Elandsfontein.

$$
\begin{aligned}
y & =-30.3494+\left(-0.0170 \times \mathrm{O}_{3}\right)+\left(0.0002 \times \mathrm{NO}_{2}\right) \\
& +\left(0.1005 \times \mathrm{H}_{2} \mathrm{~S}\right)+(0.1350 \times \mathrm{T})+(0.0102 \times \mathrm{RH}) \\
& +(0.0338 \times \mathrm{P})+(1.8185 \times \mathrm{T}-\text { gradient })
\end{aligned}
$$

For the June and July periods, Eq. (4) and the lower left panel of Fig. 16 indicate that the optimum MLR solution included only four independent variables in the equation. This low number of independent variables confirm that this time period was dominated by a much less complicated source mixture than the overall time period. From June to July, it was previously indicated that household combustion dominated eBC contributions, which is confirmed by the $\mathrm{SO}_{2}$ - and $\mathrm{NO}_{2}$ associated $\mathrm{eBC}$ increases indicated by Eq. (4). As stated earlier, the household combustion plumes measured at Elandsfontein are likely to be NO depleted, due to the stagnant nature of air masses during the evening and early morning that result in the oxidation of $\mathrm{NO}$ to $\mathrm{NO}_{2}$. This phenomenon is also indicated by Eq. (3). Lastly, increased RH will be associated with increased moisture-induced particle growth that could result in quicker aerosol deposition and therefore reduced eBC levels.

$$
\begin{aligned}
y & =1.7061+\left(0.0453 \times \mathrm{SO}_{2}\right)+(-0.1059 \times \mathrm{NO}) \\
& +\left(0.0855 \times \mathrm{NO}_{2}\right)+(-0.0191 \times \mathrm{RH})
\end{aligned}
$$

For the August and September periods, Eq. (5) and the lower right panel of Fig. 16 indicate that the optimum MLR solution included eight independent variables in the equation. Although not as low as for the June and July period, this low number of independent variables confirms that the August and September periods were less complicated than the overall time period. According to Eq. (5), increased $\mathrm{O}_{3}$ for $\mathrm{Au}-$ gust to September had a positive constant associated with it, which indicates that aged savannah and grassland fire plumes increase the eBC concentrations, while the $\mathrm{NO}_{2}$ and $\mathrm{SO}_{2}$ positive constant associations and the negative $\mathrm{NO}$ constant association indicate that household combustion still makes contributions during this time. This makes sense, since August is still regarded as a winter month with significant household combustion for space heating taking place. However, since the August and September periods already include warmer spring months (September for both years) with lower household combustion, the $\mathrm{H}_{2} \mathrm{~S}$, T, RH and T-gradient relationships observed in summer also already make a meaningful contribution.

$$
\begin{aligned}
y & =-2.549+\left(0.0511 \times \mathrm{O}_{3}\right)+\left(0.0316 \times \mathrm{SO}_{2}\right) \\
& +(-0.5737 \times \mathrm{NO})+\left(0.1840 \times \mathrm{NO}_{2}\right) \\
& +\left(0.0433 \times \mathrm{H}_{2} \mathrm{~S}\right)+(0.0469 \times \mathrm{T})+(0.0145 \times \mathrm{RH}) \\
& +(2.4877 \times \mathrm{T}-\mathrm{grad})
\end{aligned}
$$

\section{Summary and conclusions}

This paper presents the most comprehensive eBC spatial and temporal, as well as source contribution, assessments for the South African interior that has been published in the peerreviewed public domain to date. Limited EC data were also presented, which expanded the overall spatial extent covered in the paper.

Analyses of eBC and EC spatial concentration patterns at eight sites indicate that concentrations in the South African interior are in general higher than what has been reported for the developed world, e.g. western Europe. The highest levels were observed at Vaal Triangle, which were attributed to EC emissions from household combustion emanating from informal and semiformal settlements, as well as traffic and large points sources. eBC or EC levels at Elandsfontein, Amersfoort and Marikana were similar but likely originated from different sources. Elandsfontein and Amersfoort lie within the well-known $\mathrm{NO}_{2}$ hotspot over the Mpumalanga Highveld and are therefore likely to be influenced by industrial activities in this area, while Marikana is in close proximity to informal and semiformal settlements. The background sites, i.e. Welgegund, Botsalano, Louis Trichardt and Skukuza, had lower eBC or EC levels. All these background sites are likely to be affected most by regional savannah and grassland fires, which are common in southern Africa.

Similar seasonal patterns were observed at all three sites where high-resolution eBC data were collected, i.e. Elandsfontein, Marikana and Welgegund, with the highest eBC concentrations measured from June to October. These months coincide with the cold winter months of June to August that indicate possible contributions from household combustion, as well as the dry season on the South African Highveld oc- 
curring between May and mid-October, which indicates contributions from savannah and grassland fires.

Diurnal patterns indicated that at Elandsfontein industrial high stack emissions were not the most significant source, since no peaks were observed after the breakup of lower-level inversion layers. The diurnal patterns at Marikana revealed household combustion for space heating and cooking to be the most significant sources. At Welgegund, the most significant source contributions were most likely regional savannah and grassland fires.

Possible contributing eBC sources were explored in greater detail for Elandsfontein only. Industrial sources could be isolated best during the summer months of December to February, since very few savannah and grassland fires, as well as household combustion for space heating occur then. Coincidental plumes of $\mathrm{SO}_{2}, \mathrm{NO}_{2}, \mathrm{NO}$ and $\mathrm{eBC}$ were used to identify plumes from coal-fired power stations, while coincidental increases of $\mathrm{H}_{2} \mathrm{~S}$ and $\mathrm{eBC}$ characterised $\mathrm{eBC}$ contributions from pyrometallurgical smelters. During summer, coincidental increases of $\mathrm{NO}_{2}$ and $\mathrm{eBC}$ were used to identify traffic emissions. The contribution of household combustion was isolated during the coldest winter months of June and July. Coincidental increases of $\mathrm{NO}_{2}, \mathrm{SO}_{2}$ and $\mathrm{H}_{2} \mathrm{~S}$, with $\mathrm{eBC}$, which did not correlate to $\mathrm{NO}$ increases, were found to characterise household combustion plumes. Back-trajectory analyses and wind roses supported the validity of all the aforementioned source associations. Savannah and grassland fire plumes could not be isolated since $\mathrm{CO}$ was not measured at Elandsfontein. However, the general baseline increase in eBC levels between September (the peak fire frequency period) and the summer months (with virtually no savannah and grassland fires) could be calculated and attributed to savannah and grassland fire eBC emissions. At Elandsfontein, the $\mathrm{eBC}$ concentration in September was comparable to the $\mathrm{eBC}$ concentration from June to July, which indicates that at this location domestic heating and regional scale savannah and grassland fires are equally significant sources of eBC. Furthermore, MLR analyses supported the seasonality of eBC sources at Elandsfontein.

Although the source strengths of coal-fired power stations, pyrometallurgical smelters and traffic emissions were lower than that of household combustion, as well as savannah and grassland fires, the first mentioned sources contribute year round, while the latter only contributed significantly in May to August, and June to September, respectively. Of the fresh industrial plumes, the highest eBC concentrations were associated with pyrometallurgical smelters. This is a very significant finding, since coal-fired power stations and petrochemical operations have in the past been blamed for most of the pollution problems on the Mpumalanga Highveld (mainly due to the $\mathrm{NO}_{2}$ hotspot over this area). Therefore, pyrometallurgical sources in this area need to be considered in greater detail in future studies.

Lastly, the calculated emission ratios of $\mathrm{eBC}$ and gaseous species that were presented could be used in future studies to assess the eBC emission inventories for industrial and domestic sources in South Africa.

Data availability. The data for this paper are available upon request from Paul Beukes (paul.beukes@nwu.ac.za) or Ville Vakkari (ville.vakkari@fmi.fi).

Competing interests. The authors declare that they have no conflict of interest.

Acknowledgements. The European Union Framework Programme 6 (EU FP6), Eskom Holdings SOC Ltd and Sasol Technology R\&D (Pty) Limited are acknowledged for funding. V. Vakkari was a beneficiary of an AXA Research Fund postdoctoral grant. The financial support by the Saastamoinen Foundation is gratefully acknowledged for funding P. Tiitta. The National Research Foundation (NRF) is acknowledged for providing research financial assistance (bursaries/scholarships) to P. Maritz, A. D. Venter and K. Jaars. Opinions expressed and conclusions arrived at are those of the authors and are not necessarily attributed to those of the NRF.

Edited by: A. Petzold

Reviewed by: two anonymous referees

\section{References}

Air Resources Laboratory, Gridded Meteorological Data Archives, available at: http://www.ready.noaa.gov/archives.php, last access: 24 February 2014a.

Air Resources Laboratory, Gridded Meteorological Data Archives, available at: http://www.arl.noaa.gov/faq_hg17.php, last access: 14 February 2014b.

Andreae, M. O. and Gelencsér, A.: Black carbon or brown carbon? The nature of light-absorbing carbonaceous aerosols, Atmos. Chem. Phys., 6, 3131-3148, doi:10.5194/acp-6-3131-2006, 2006.

Aurela, M., Beukes, J. P., Vakkari, V., Van Zyl, P. G., Teinilä, K., Saarikoski S., and Laakso L.: The composition of ambient and fresh biomass burning aerosols at a savannah site, South Africa, S. Afr. J. Sci., 112(5/6), 2015-0223, 8 pp., doi:10.17159/sajs.2016/20150223, 2016.

Awang, N. R., Ramli, N. Y., Ahmad, S., and Elbayoumi, M.: Multivariate methods to predict ground level ozone during daytime, nighttime, and critical conversion time in urban areas, Atmos. Environ. 43, 3918-3924, doi:10.5094/APR.2015.081, 2015.

Baldauf, R. W., Lane, D. D., Marotz, G. A., and Wiener, R. W.: Performance evaluation of the portable MiniVOL particulate matter sampler, Atmos. Environ., 35, 6087-6091, doi:10.1016/S13522310(01)00403-4, 2001.

Beukes, J. P., Van Zyl, P. G., and Ras, M.: Treatment of Cr(VI)containing wastes in the South African ferrochrome industry a review of currently applied methods, J. South. Afr. Inst. Min. Metall., 112, 347-352, 2012.

Beukes, J. P., Vakkari, V., Van Zyl, P. G., Venter, A. D., Josipovic, M., Jaars, K., Tiita, P., Siebert, S., Pienaar, J. J., Kulmala, M., 
and Laakso, L.: Welgegund: long-term land atmosphere measurement platform in South Africa, iLeaps Newsletter, 12, 24-25, 2013a.

Beukes, J. P., Vakkari, V., Van Zyl, P. G., Venter, A. D., Josipovic, M., Jaars, K., Tiitta, P., Kulmala, M., Worsnop, D., Pienaar, J. J., Virkkula, A. and Laakso, L.: Source region plume characterisation of the interior of South Africa as observed at Welgegund, Clean Air Journal, 23, 7-10, 2013b.

Bond, T., Streets, D. G., Yarber, K. F., Nelson, S. M., Woo, J.H., and Klimont, Z.: A technology-based global inventory of black and organic carbon emissions from combustion, J. Geophys. Res., 109, D14203, doi:10.1029/2003JD003697, 2004.

Bond, T., Venkataraman, C., and Masera, O.: Global atmospheric impacts of residential fuels, Energy Sustain. Dev., 8, 20-32, doi:10.1016/S0973-0826(08)60464-0, 2004.

Bond, T. C., Doherty, S. J., Fahey, D. W., Forster, P. M., Berntsen, T., DeAngelo, B. J., Flanner, M. G., Ghan, S., Kärcher, B., Koch, D., Kinne, S., Kondo, Y., Quinn, P., Sarofim, M. C., Schultz, M. G., Schulz, M., Venkataraman, C., Zhang, H., Zhang, S., Bellouin, N., Guttikunda, S. K., Hopke, P. K., Jacobson, M. Z., Kaiser, J. W., Klimont, Z., Lohmann, U., Schwarz, J. P., Shindell, D., Storelvmo, T., Warren, S. G., and Zender, C. S.: Bounding the role of black carbon in the climate system: A scientific assessment, J. Geophys. Res.-Atmos., 118, 5380-5552, doi:10.1002/jgrd.50171, 2013.

Cachier, H., Liousse, C., Buat-Menard, P., and Gaudichet, A.: Particulate content of savanna fire emissions, J. Atmos. Chem., 22, 123-148, doi:10.1007/BF00708185, 1995.

Chow, J. C., Watson, J. G., Pritchett, L. C., Pierson, W. R., Frazier, C. A., and Purcell, R. G.: The DRI thermal/optical reflectance carbon analysis system: description, evaluation and applications in U.S. Air quality studies, Atmos. Environ., 27, 1185-1201, doi:10.1016/0960-1686(93)90245-T, 1993.

Chow, J. C., Watson, J. G., Crow, D., Lowenthal, D. H., and Merrifield, T.: Comparison of IMPROVE and NIOSH carbon measurements, Aerosol Sci. Tech., 34, 23-24, 2001.

Chow, J. C., Watson, J. G., Kuhns, H., Etyemezian, V., Lowenthal, D. H., Crow, D., Kohl, S. D., Engelbrecht, J. P., and Green, M. C.: Source profiles for industrial, mobile, and area sources in the Big Bend Regional Aerosol Visibility and Observational study, Chemosphere, 54, 185-208, doi:10.1016/j.chemosphere.2003.07.004, 2004.

Collett, K., Piketh, S., and Ross, K.: An assessment of the atmospheric nitrogen budget on the South African Highveld, S. Afr. J. Sci., 106(5/6), 220, 9 pp., doi:10.4102/sajs.v106i5/6.220, 2010.

Conradie, E. H., Van Zyl, P. G., Pienaar, J. J., Beukes, J. P., Galy-Lacaux, C., Venter, A. D., and Mkhatshwa, G. V.: The chemical composition and fluxes of atmospheric wet deposition at four sites in South Africa, Atmos. Environ., 146, 113-131, doi:10.1016/j.atmosenv.2016.07.033, 2016.

Cooke, W. F. and Wilson, J. N.: A global black carbon aerosol model, J. Geophys. Res., 101D, 19395-19408, doi:10.1029/96JD00671, 1996.

Du Preez, S. P., Beukes, J. P. and Van Zyl, P. G.: Cr(VI) generation during flaring of CO-rich off-gas from closed ferrochromium submerged arc furnaces, Metall. Mater. Trans. B, 46, 1002-1010, doi:10.1007/s11663-014-0244-3, 2015.
Draxler, R. R. and Hess, G. D.: Description of the HYSPLIT 4 Modelling System, NOAA Technical Memorandum ERL ARL-224, 2004.

Environmental Analysis Facility (EAF). DRI Standard operating procedure, 86 pp., Laboratoired'Aérologie - UMR 5560, available at: http://www.aero.obs-mip.fr/spip.php?article489 (last access: 16 June 2016), 2008.

Formenti, P., Elbert, W., Maenhaut, W., Haywood, J., Osborne, S., and Andreae, M. O.: Inorganic and carbonaceous aerosols during the Southern African Regional Science Initiative (SAFARI 2000) experiment: Chemical characteristics, physical properties, and emission data for smoke from African biomass burning, J. Geophys. Res., 108, 8488, doi:10.1029/2002JD002408, 2003.

Galy-Lacaux, C., Al Ourabi, H., Lacaux, J.-P., Pont, V., Galloway, J., Mphepya, J., Pienaar, K., Sigha, L., and Yoboué, V.: Dry and wet atmospheric nitrogen deposition in Africa, IGAC Newsletter, January 2003, 6-11, 2003.

Garstang, M., Tyson, M., Swap, R., Edwards, M., Kåallberg, P., and Lindesay, J. A.: Horizontal and vertical transport of air over southern Africa, J. Geophys. Res., 101, 23721-23736, doi:10.1029/95JD00844, 1996.

Guillame, B., Liousse, C., Galy-Lacaux, C., Rosset, R., Gardrat, E., Cachier, H., Bessagnet, B., and Poisson, N.: Modeling exceptional high concentrations of carbonaceous aerosols observed at Pic du Midi in spring-summer 2003: Comparison with Sonnblick and Puy de Dôme, Atmos. Environ., 42, 5140-5149, doi:10.1016/j.atmosenv.2008.02.024, 2008.

Hansen, A. D. A., Rosen, H., and Novakov, T.: The Aethalometer: an instrument for real-time measurement of optical absorption by aerosol particles, Sci. Total Environ., 36, 191-196, doi:10.1016/0048-9697(84)90265-1, 1984.

Hirsikko, A., Vakkari, V., Tiitta, P., Manninen, H. E., Gagné, S., Laakso, H., Kulmala, M., Mirme, A., Mirme, S., Mabaso, D., Beukes, J. P., and Laakso, L.: Characterisation of sub-micron particle number concentrations and formation events in the western Bushveld Igneous Complex, South Africa, Atmos. Chem. Phys., 12, 3951-3967, doi:10.5194/acp-12-3951-2012, 2012.

HYSPLIT User's Guide-Version 4. Last revised: April 2013, available at: http://www.arl.noaa.gov/documents/reports/hysplit_ user_guide.pdf, last access: 13 February 2014.

Hyvärinen, A.-P., Vakkari, V., Laakso, L., Hooda, R. K., Sharma, V. P., Panwar, T. S., Beukes, J. P., van Zyl, P. G., Josipovic, M., Garland, R. M., Andreae, M. O., Pöschl, U., and Petzold, A. Correction for a measurement artifact of the Multi-Angle Absorption Photometer (MAAP) at high black carbon mass concentration levels, Atmos. Meas. Tech., 6, 81-90, doi:10.5194/amt-681-2013, 2013.

IPCC: Summary for Policymakers, in: Climate Change 2013: The Physical Science Basis. Contribution of Working Group I to the Fifth Assessment Report of the Intergovernmental Panel on Climate Change, edited by: Stocker, T. F., Qin, D., Plattner, G. K., Tignor, M., Allen, S. K., Boschung, J., Nauels, A., Xia, Y., Bex, V., and Midgley, P. M., Cambridge University Press, Cambridge, United Kingdom and New York, NY, USA, 2013.

Jaars, K., Beukes, J. P., van Zyl, P. G., Venter, A. D., Josipovic, M., Pienaar, J. J., Vakkari, V., Aaltonen, H., Laakso, H., Kulmala, M., Tiitta, P., Guenther, A., Hellén, H., Laakso, L., and Hakola, H.: Ambient aromatic hydrocarbon measurements at 
Welgegund, South Africa, Atmos. Chem. Phys., 14, 7075-7089, doi:10.5194/acp-14-7075-2014, 2014.

Jacobson, M.: Climate response of fossil fuel and biofuel soot, accounting for soot's feedback to snow and sea ice albedo and emissivity, J. Geophys. Res.-Atmos., 109, D21201, doi:10.1029/2004JD004945, 2004.

Järvi, L., Junninen, H., Karppinen, A., Hillamo, R., Virkkula, A., Mäkelä, T., Pakkanen, T., and Kulmala, M.: Temporal variations in black carbon concentrations with different time scales in Helsinki during 1996-2005, Atmos. Chem. Phys., 8, 1017-1027, doi:10.5194/acp-8-1017-2008, 2008.

Kanakidou, M., Seinfeld, J. H., Pandis, S. N., Barnes, I., Dentener, F. J., Facchini, M. C., Van Dingenen, R., Ervens, B., Nenes, A., Nielsen, C. J., Swietlicki, E., Putaud, J. P., Balkanski, Y., Fuzzi, S., Horth, J., Moortgat, G. K., Winterhalter, R., Myhre, C. E. L., Tsigaridis, K., Vignati, E., Stephanou, E. G., and Wilson, J.: Organic aerosol and global climate modelling: a review, Atmos. Chem. Phys., 5, 1053-1123, doi:10.5194/acp-5-1053-2005, 2005.

Korhonen, K., Giannakaki, E., Mielonen, T., Pfüller, A., Laakso, L., Vakkari, V., Baars, H., Engelmann, R., Beukes, J. P., Van Zyl, P. G., Ramandh, A., Ntsangwane, L., Josipovic, M., Tiitta, P., Fourie, G., Ngwana, I., Chiloane, K., and Komppula, M.: Atmospheric boundary layer top height in South Africa: measurements with lidar and radiosonde compared to three atmospheric models, Atmos. Chem. Phys., 14, 4263-4278, doi:10.5194/acp-14-42632014, 2014.

Kuik, F., Lauer, A., Beukes, J. P., Van Zyl, P. G., Josipovic, M., Vakkari, V., Laakso, L., and Feig, G. T.: The anthropogenic contribution to atmospheric black carbon concentrations in southern Africa: a WRF-Chem modeling study, Atmos. Chem. Phys., 15, 8809-8830, doi:10.5194/acp-15-8809-2015, 2015.

Kulmala, M., Asmi, A., Lappalainen, H. K., Carslaw, K. S., Pöschl, U., Baltensperger, U., Hov, Ø., Brenquier, J.-L., Pandis, S. N., Facchini, M. C., Hansson, H.-C., Wiedensohler, A., and O'Dowd, C. D.: Introduction: European Integrated Project on Aerosol Cloud Climate and Air Quality interactions (EUCAARI) - integrating aerosol research from nano to global scales, Atmos. Chem. Phys., 9, 2825-2841, doi:10.5194/acp-9-2825-2009, 2009.

Laakso, L., Vakkari, V., Virkkula, A., Laakso, H., Backman, J., Kulmala, M., Beukes, J. P., van Zyl, P. G., Tiitta, P., Josipovic, M., Pienaar, J. J., Chiloane, K., Gilardoni, S., Vignati, E., Wiedensohler, A., Tuch, T., Birmili, W., Piketh, S., Collett, K., Fourie, G. D., Komppula, M., Lihavainen, H., de Leeuw, G., and Kerminen, V.-M.: South African EUCAARI measurements: seasonal variation of trace gases and aerosol optical properties, Atmos. Chem. Phys., 12, 1847-1864, doi:10.5194/acp-12-1847-2012, 2012.

Liousse, C., Penner, J. E., Chuang, C., Walton, J. J., Eddleman, H., and Cachier, H.: A global three-dimensional model study of carbonaceous aerosols, J. Geophys. Res., 105, 26871-26890, 1996.

Lourens, A. S., Beukes, J. P., Van Zyl, P. G., Fourie, G. D., Burger, J. W., Pienaar, J. J., Read, C. E., and Jordaan, J. H.: Spatial and temporal assessment of gaseous pollutants in the Highveld of South Africa, S. Afr. J. Sci., 07(1/2), 269, 8 pp., doi:10.4102/sajs.v107i1/2.269, 2011.

Lourens, A. S. M., Butler, T. M., Beukes, J. P., Van Zyl, P. G., Beirle, S., Wagner, T., Heue, K.-P., Pienaar, J. J., Fourie, G. D., and Lawrence, M.G.: Re-evaluating the $\mathrm{NO}_{2}$ hotspot over the
South African Highveld, S. Afr. J. Sci., 108(11/12), 1146, 6 pp., doi:10.4102/sajs.v108i11/12.1146, 2012.

Lourens, A. S. M., Butler, T. M., Beukes, J. P., Van Zyl, P. G., Fourie, G. D., and Lawrence, M. G.: Investigating atmospheric photochemistry in the Johannesburg-Pretoria megacity using a box model, S. Afr. J. Sci., 112(1/2), 2015-0169, 11 pp., doi:10.17159/sajs.2016/2015-0169, 2016.

Mafusire, G., Annegarn, H. J., Vakkari, V., Beukes, J. P., Josipovic, M., Van Zyl, P. G., and Laakso, L.: Submicrometer aerosols and excess $\mathrm{CO}$ as tracers for biomass burning air mass transport over southern Africa, J. Geophys. Res.-Atmos., 121, 10262-10282, doi:10.1002/2015JD023965, 2016.

Maritz, P., Beukes, J. P., Van Zyl, P. G. Conradie, E. H., Liousse, C., Galy-Lacau, C., Castéra, P., Ramandh, A., Mkhatshwa, G., Venter, A. D., and Pienaar, J. J.: Spatial and temporal assessment of organic and black carbon at four sites in the interior of South Africa, Clean Air Journal, 25, 20-33, doi:10.17159/2410972X/2015/v25n1a1, 2015.

Martins, J. J.: Concentrations and deposition of atmospheric species at regional sites in southern Africa, MSc thesis NWU Potchefstroom, 224 pp., 2009.

Martins, J. J., Dhammapala, R. S., Lachmann, G., Galy-Lacaux, C., and Pienaar, J. J.: Long-term measurements of sulphur dioxide, nitrogen dioxide, ammonia, nitric acid and ozone in southern Africa using passive samplers, S. Afr. J. Sci., 103, 336-342, 2007.

Masiello, C. A.: New directions in black carbon organic geochemistry, Mar. Chem., 92, 201-213, doi:10.1016/j.marchem.2004.06.043, 2004.

Mphepya, J. N., Pienaar, J. J., Galy-Lacaux, C., Held, G., and Turner, C. R.: Precipitation Chemistry in SemiArid Areas of Southern Africa: A Case Study of a Rural and an Industrial Site, J. Atmos. Chem., 47, 1-24, doi:10.1023/B:JOCH.0000012240.09119.c4, 2004.

Mphepya, J. N., Galy-Lacaux, C., Galy-Lacaux, J. P., Held, G., and Pienaar, J. J.: Precipitation Chemistry and Wet Deposition in the Kruger National Park, South Africa, J. Atmos. Chem., 53, 169183, doi:10.1007/s10874-005-9005-7, 2006.

NASA: available at: http://gcmd.nasa.gov/records/GCMD_gov. noaa.ncdc.C00075.html, last access: 28 April 2015.

Petzold, A. and Schönlinner, M.: Multi-angle absorption photometry: a new method for the measurement of aerosol light absorption and atmospheric black carbon, J. Aerosol Sci., 35, 421-441, doi:10.1016/j.jaerosci.2003.09.005, 2004.

Petzold, A., Ogren, J. A., Fiebig, M., Laj, P., Li, S.-M., Baltensperger, U., Holzer-Popp, T., Kinne, S., Pappalardo, G., Sugimoto, N., Wehrli, C., Wiedensohler, A., and Zhang, X.-Y.: Recommendations for reporting "black carbon" measurements, Atmos. Chem. Phys., 13, 8365-8379, doi:10.5194/acp-13-83652013, 2013.

Pope, C. A., Burnett, R. T., Thun, M. J., Calle, E. E., Krewski, D., Ito, K., and Thurston, G. D.: Lung cancer, cardiopulmonary mortality, and long-term exposure to fine particulate air pollution, J. Amer. Med. Assoc., 287, 1132-1141, 2002.

Pöschl, U.: Atmospheric Aerosols: Composition, Transformation, Climate and Health Effects, Atmospheric Chemistry: Reviews, Angew. Chem. Int. Edit., 44, 7520-7540, doi:10.1002/anie.200501122, 2005. 
Putaud, J.-P., Raes, F., Van Dingenen, R., Brüggemann, E., Facchini, M.-C., Decesari, S., Fuzzi, S., Gehrig, R., Hüglin, C., Laj, P., Lorbeer, G., Maenhaut, W., Mihalopoulos, N., Müller, K., Querol, X., Rodriguez, S., Schneider, J., Spindler, G., ten Brink, H., Tørseth, K., and Wiedensohler, A.: A European aerosol phenomenology e 2: chemical characteristics of particulate matter at kerbside, urban, rural and background sites in Europe, Atmos. Environ., 38, 2579-2595, doi:10.1016/j.atmosenv.2004.01.041, 2004.

Ramanathan, V. and Carmichael, G.: Global and regional climate changes due to black carbon, Nat. Geosci., 1, 221-227, doi:10.1038/ngeo156, 2008.

Riddle, E. E., Voss, P. B., Stohl, A., Holcomb, D., Maczka, D., Washburn, K., and Talbot, R. W.: Trajectory model validation using newly developed altitude-controlled balloons during the International Consortium for Atmospheric Research on Transport and Transformations 2004 campaign. J. Geophys. Res., 111, D23S57, doi:10.1029/2006JD007456, 2006.

Roy, D. P., Boschetti, L., Justice, C. O., and Ju, J.: The collection 5 MODIS burned area product: Global evaluation by comparison with the MODIS active fire product, Remote Sens. Environ., 112, 3690-3707, doi:10.1016/j.rse.2008.05.013, 2008.

Saha, A. and Despiau, S.: Seasonal and diurnal variations of black carbon aerosols over a Mediterranean coastal zone, Atmos. Res., 92, 27-41, doi:10.1016/j.atmosres.2008.07.007, 2009.

Sehloho, R. M.: An assessment of atmospheric organic and black carbon at Welgegund, $\mathrm{PhD}$ thesis in preparation, North-West University, Potchefstroom Campus, South Africa, 2017.

Shindell, D. T., Chin, M., Dentener, F., Doherty, R. M., Faluvegi, G., Fiore, A. M., Hess, P., Koch, D. M., MacKenzie, I. A., Sanderson, M. G., Schultz, M. G., Schulz, M., Stevenson, D. S., Teich, H., Textor, C., Wild, O., Bergmann, D. J., Bey, I., Bian, H., Cuvelier, C., Duncan, B. N., Folberth, G., Horowitz, L. W., Jonson, J., Kaminski, J. W., Marmer, E., Park, R., Pringle, K. J., Schroeder, S., Szopa, S., Takemura, T., Zeng, G., Keating, T. J., and Zuber, A.: A multi-model assessment of pollution transport to the Arctic, Atmos. Chem. Phys., 8, 5353-5372, doi:10.5194/acp-85353-2008, 2008.

Stohl, A.: Computation, accuracy and application of trajectories - a review and bibliography, Atmos. Environ., 32, 947-966, doi:10.1016/S1352-2310(97)00457-3, 1998.

Swap, R. J., Aranibar, J. N., Dowty, P. R., Gilhooly (III), W. P., and Macko, S. A.: Natural abundance of ${ }^{13} \mathrm{C}$ and ${ }^{15} \mathrm{~N}$ in $\mathrm{C}_{3}$ and $\mathrm{C}_{4}$ vegetation of southern Africa: patterns and implications, Glob. Change Biol., 10, 350-358, doi:10.1111/j.13652486.2003.00702.x, 2004.

Tiitta, P., Vakkari, V., Croteau, P., Beukes, J. P., van Zyl, P. G., Josipovic, M., Venter, A. D., Jaars, K., Pienaar, J. J., Ng, N. L., Canagaratna, M. R., Jayne, J. T., Kerminen, V.-M., Kokkola, H., Kulmala, M., Laaksonen, A., Worsnop, D. R., and Laakso, L.: Chemical composition, main sources and temporal variability of $\mathrm{PM}_{1}$ aerosols in southern African grassland, Atmos. Chem. Phys., 14, 1909-1927, doi:10.5194/acp-14-1909-2014, 2014.
Tummon, F., Solmon, F., Liousse, C., and Tadross, M.: Simulation of the direct and semidirect aerosol effects on the southern Africa regional climate during the biomass burning season, J. Geophys. Res.-Atmos., 115, D19206, doi:10.1029/2009JD013738, 2010.

Vakkari, V., Kerminen, V.-M., Beukes, J. P., Tiitta, P., Van Zyl, P. G., Josipovic, M., Venter, A. D., Jaars, K., Worsnop, D. R., Kulmala, M., and Laakso, L.: Rapid changes in biomass burning aerosols by atmospheric oxidation, Geophys. Res. Lett., 41, 2644-2651, doi:10.1002/2014GL059396, 2014.

Vakkari, V., Beukes, J. P., Laakso, H., Mabaso, D., Pienaar, J. J., Kulmala, M., and Laakso, L.: Long-term observations of aerosol size distributions in semi-clean and polluted savannah in South Africa, Atmos. Chem. Phys., 13, 1751-1770, doi:10.5194/acp13-1751-2013, 2013.

Venter, A. D., Vakkari, V., Beukes, J. P., Van Zyl, P. G., Laakso, H., Mabaso, D., Tiitta, P., Josipovic, M., Kulmala, M., Pienaar, J. J., and Laakso, L.: An air quality assessment in the industrialised western Bushveld Igneous Complex, South Africa, S. Afr. J. Sci., 108(9/10), 1059, 10 pp., doi:10.4102/sajs.v108i9/10.1059, 2012.

Venter, A. D., Beukes, J. P., van Zyl, P. G., Brunke, E.-G., Labuschagne, C., Slemr, F., Ebinghaus, R., and Kock, H.: Statistical exploration of gaseous elemental mercury (GEM) measured at Cape Point from 2007 to 2011, Atmos. Chem. Phys., 15, 10271-10280, doi:10.5194/acp-15-10271-2015, 2015.

Venter, A. D., Beukes, J. P., Van Zyl, P. G., Josipovic, M., Jaars, K., and Vakkari, V.: Regional atmospheric $\mathrm{Cr}(\mathrm{VI})$ pollution from the Bushveld Complex, South Africa, Atmos. Pollut. Res., 7, 762767, doi:10.1016/j.apr.2016.03.009, 2016.

Viidanoja, J., Sillanpää, M., Laakia, J., Kerminen, V.-M., Hillamo, R., Aarnio, P., and Koskentalo, T.: Organic and black carbon in $\mathrm{PM}_{2.5}$ and $\mathrm{PM}_{10}: 1$ year of data from an urban site in Helsinki, Finland, Atmos. Environ., 36, 3183-3193, doi:10.1016/S13522310(02)00205-4, 2002.

Watson, J. G., Chow, J. C., and Chen, L.-W. A.: Summary of Organic and Elemental Carbon/Black Carbon Analysis Methods and Intercomparisons, Aerosol Air Qual. Res., 5, 65-102, 2005.

Wolf, E. W. and Cachier, H.: Concentrations and seasonal cycle of black carbon in aerosol at a coastal Antarctic station, J. Geophys. Res., 103D, 11033-11041, 1998.

Yttri, K. E., Aas, W., Bjerke, A., Cape, J. N., Cavalli, F., Ceburnis, D., Dye, C., Emblico, L., Facchini, M. C., Forster, C., Hanssen, J. E., Hansson, H. C., Jennings, S. G., Maenhaut, W., Putaud, J. P., and Tørseth, K.: Elemental and organic carbon in $\mathrm{PM}_{10}$ : a one year measurement campaign within the European Monitoring and Evaluation Programme EMEP, Atmos. Chem. Phys., 7, 5711-5725, doi:10.5194/acp-7-5711-2007, 2007. 